\title{
Oxygen Metabolism in Chloroplast
}

\author{
Boris Ivanov, Marina Kozuleva and Maria Mubarakshina \\ Institute of Basic Biological Problems Russian Academy of Sciences \\ Russia
}

\section{Introduction}

Oxygen was almost non-existent in the Earth's atmosphere before the oxygenic photosynthetic bacteria appeared. Since $\mathrm{O}_{2}$ is capable of combining with most chemical elements, the stable level of $\mathrm{O}_{2}$ in the atmosphere is the result of it being continuously regenerated by the oxygenic photosynthetic organisms, i.e. the cyanobacteria, algae and plants.

The molecular mechanism of water oxidation to $\mathrm{O}_{2}$ is still unclear, although many structural details are known and some of the details of the charge accumulating cycle are well worked out (reviewed in Barber, 2008; Brudvig, 2008). The water-oxidizing complex, with a $\mathrm{Mn}_{4} \mathrm{Ca}$ cluster as the active site, is an integral part of the Photosystem II (PSII), one of the main complexes of the photosynthetic electron transport chain (PETC). When the energy of a quantum of light absorbed by a chlorophyll molecule in this photosystem reaches the reaction center, photochemistry occurs leading to charge separation. The electron is used to reduce plastoquinone, while the electron hole is used to oxidize a $\mathrm{Mn}$ ion of the cluster and eventually used to oxidize water. Two sequential photochemical turnovers are required to reduce quinone to quinol, while four sequential turnovers are required to oxidize two water molecules forming $\mathrm{O}_{2}$. It is important to note that the water oxidation/oxygen evolution process is the most easily damaged function of the PETC under stress conditions.

Sixty years ago, the first data were published indicating the light-induced reduction of $\mathrm{O}_{2}$ in the chloroplasts (Mehler, 1951) (see 2.2). There has been much debate concerning what is the proportion of the total electron flow from water that ends up on $\mathrm{O}_{2}$. It seems likely that there is no generally applicable answer to this question and it seems that the best answer is that it depends on the conditions. Under continuous illumination the proportion of electrons transferred to $\mathrm{O}_{2}$ was reported to be less than $10 \%$ in $\mathrm{C}_{3}$-plants, up to $15 \%$ in $\mathrm{C}_{4}$-plants (mesophyll cells), and even $30 \%$ in algae (Badger et al., 2000). In a recent study with leaves of Hibiscus rosa-sinensis, it was concluded that in this plant it was almost $40 \%$ (Kuvykin et al., 2008). We believe that both the rate of oxygen reduction and its proportion of the total electron transport depends on i) the plant species, the genome of which determines the range of these values, ii) environmental factors (light, temperature, mineral nutrition, supply of water, and so on), and iii) the age of the plant.

The reduction of $\mathrm{O}_{2}$ by the PETC in chloroplasts results in the formation of a series of reduced forms of $\mathrm{O}_{2}$ that are termed Reactive Oxygen Species (ROS), namely, superoxide anion radical $\left(\mathrm{O}_{2}{ }^{\cdot-}\right)$, hydrogen peroxide $\left(\mathrm{H}_{2} \mathrm{O}_{2}\right)$, and hydroxyl radical $(\mathrm{OH} \cdot)$. ROS also 
include the singlet oxygen $\left({ }^{1} \mathrm{O}_{2}\right)$, which is not generated by $\mathrm{O}_{2}$ reduction but by energy transfer from other molecule, mainly from excited chlorophyll triplet state (see 2.2.2).

The above ROS-generating reactions should be distinguished from ROS-mediated reactions, in which the ROS themselves interact with components of the chloroplast. The reactions of both types have "positive" and "negative" effects on chloroplast functions. The occurrence of both types of ROS reactions and to what degree their influence is positive or negative can change as conditions change during the life of the plant, being primarily determined by the level of stress encountered.

\section{Oxygen metabolism in chloroplast}

\subsection{The properties of $\mathrm{O}_{2}$ molecule and reactive oxygen species}

Under usual conditions in the nature, oxygen is a gas composed of diatomic molecules $\mathrm{O}_{2}$, dioxygen. Triplet is the ground state of the dioxygen since the molecule has two electrons with parallel spins in two antibonding molecular orbitals. Since these electrons are unpaired, dioxygen is a biradical. However, the reaction of this biradical with cell components has quantum-mechanical constraint because these components are in the singlet state, i.e. they have the valence electrons with antiparallel spins. Due to the above reasons the spontaneous reactions of cell metabolites with dioxygen are highly retarded despite its high oxidizing potential, $\mathrm{E}_{0}^{\prime}=+0.845 \mathrm{~V}$ of the full reduction of $\mathrm{O}_{2}$ to $\mathrm{H}_{2} \mathrm{O}$. Such situation is saving for organisms, and the reactions of cell metabolites with $\mathrm{O}_{2}$ proceed generally with involvement of enzymes, which activate a substrate to speed up these reactions. However the oxidation of cell components can readily proceed by ROS.

Singlet oxygen, ${ }^{1} \mathrm{O}_{2}$, is formed as the result of the spin flip of one of unpaired electrons. The transformation of ${ }^{1} \mathrm{O}_{2}$ to triplet is relatively slow; its lifetime in the cell was estimated to be appr. 3 s (Hatz et al., 2007). This estimation is higher than the previous one for cytoplasm, $0.2 \mu$ s (Matheson et al., 1975). In the apolar media this lifetime is higher, $12 \mu \mathrm{s}$ in ethanol and $24 \mu \mathrm{s}$ in benzene, and in the heavy water the lifetime increases almost twentyfold and reaches $68 \mu$ s (Krasnovsky, 1998). The chloroplast is a prevailing source of ${ }^{1} \mathrm{O}_{2}$ in the living organisms.

Superoxide anion radical, $\mathrm{O}_{2}{ }^{--}$, can appear if one additional electron is transferred to the antibonding orbital of $\mathrm{O}_{2}$. This transfer is possible only if a donor molecule has a redox potential close or lower than the redox potential of pair $\mathrm{O}_{2} / \mathrm{O}_{2}{ }^{--}$. In the aqueous solutions $\mathrm{E}_{0}^{\prime}\left(\mathrm{O}_{2} / \mathrm{O}_{2}{ }^{--}\right)$is equal to $-0.16 \mathrm{~V}$ vs. the normal hydrogen electrode $(\mathrm{NHE})$ at $1 \mathrm{M} \mathrm{O}_{2}$. This value should be used in all thermodynamic consideration of the reactions in the aqueous solutions, instead of $-0.33 \mathrm{~V}$, which is the standard potential at $1 \mathrm{~atm}$ of $\mathrm{O}_{2}$. The value of the midpoint redox-potential in aprotic media is much lower, in the region $-0.55 \div-0.6 \mathrm{~V} v s$. NHE (Afanas'ev, 1989). Thus in aprotic media $\mathrm{O}_{2}{ }^{--}$is a very strong reductant.

The heavy solvation of $\mathrm{O}_{2}{ }^{-}$- in aqueous solutions evidently determines its moderate activity in deprotonation reaction in this media; $\mathrm{pK}_{\mathrm{a}}$ value of perhydroxyl radical, $\mathrm{HO}_{2}{ }^{\circ}$, is equal to 4.8. Thus in the aqueous solutions at physiological $\mathrm{pH} 7.7$ the amount of $\mathrm{HO}_{2}{ }^{\bullet}$ is near $0.25 \%$ from total amount of $\mathrm{HO}_{2}{ }^{\bullet}+\mathrm{O}_{2}{ }^{\bullet}$. The basicity of superoxide ion is much stronger in aprotic media; it was estimated that 'thermodinamic' value of $\mathrm{pK}_{\mathrm{a}}$ is close to 12 . However more detailed consideration of full deprotonation process leads to a statement that in such media 
$\mathrm{O}_{2}{ }^{--}$should be considered as a deprotonating agent with $\mathrm{pK}_{\mathrm{a}}$ of approximately 24 (Afanas'ev et al., 1987). Moreover considering deprotonation of any substrate by $\mathrm{O}_{2}{ }^{--}$it is necessary to take into account that the basicity of proton donors can also increase in aprotic medium, and e.g. the rate constant of deprotonation of a-tocopherol by $\mathrm{O}_{2}{ }^{--}$is higher in water than in aprotic solvents (Afanas'ev et al., 1987). Being the neutral free radical, $\mathrm{HO}_{2}{ }^{\circ}$ cannot abstract a proton, but it can abstract a hydrogen atom from substrates with active C$\mathrm{H}$ bonds, initiating fatty acid peroxidation (see further).

$\mathrm{O}_{2}{ }^{--}$ion is rather stable even in aqueous solution; the half-life of $\mathrm{O}_{2}{ }^{--}$was found to be close to $15 \mathrm{~s}$ at $\mathrm{pH} 11$ (Fujiwara et al., 2006). The $\mathrm{pH}$ value is very important since the rate constant of spontaneous dismutation (Reaction 1) has maximum at $\mathrm{pH} 4.8$ being equal to $10^{8} \mathrm{M}^{-1} \mathrm{~s}^{-1}$, and it sharply decreases in more alkaline media to $10^{5} \mathrm{M}^{-1} \mathrm{~s}^{-1}$ at $\mathrm{pH}$ 7.7.

$$
\mathrm{O}_{2} \cdot-+\mathrm{O}_{2} \cdot-\rightarrow \mathrm{H}_{2} \mathrm{O}_{2}+\mathrm{O}_{2}
$$

The living cells contain the special enzyme superoxide dismutase (SOD), which catalyzes the dismutation of $\mathrm{O}_{2}{ }^{--}$and determines a lifetime of $\mathrm{O}_{2}{ }^{-}{ }^{-}$, and thus the possibility of its involvement in biochemical processes (see further). In the aprotic solvents the $\mathrm{O}_{2}{ }^{-}$ dismutation is prohibited, and e.g. in dimethylformamid $\mathrm{O}_{2}{ }^{--}$can persist almost one month (Wei et al., 2004).

$\mathrm{O}_{2}{ }^{--}$can interpenetrate cell membranes; the permeability coefficient of the soybean phospholipid bilayer for $\mathrm{O}_{2}{ }^{\bullet-}$ was estimated to be $20 \mathrm{~nm} \mathrm{~s}^{-1}$ (Takahashi \& Asada, 1983). The permeability of the egg yolk phospholipid membrane for $\mathrm{HO}_{2} \cdot$ was estimated to be than for $\mathrm{O}_{2} \cdot-$ by almost three orders greater (Gus'kova et al., 1984).

Hydrogen peroxide, $\mathrm{H}_{2} \mathrm{O}_{2}$, is the most stable ROS. $\mathrm{E}_{0}^{\prime}\left(\mathrm{O}_{2}{ }^{--} / \mathrm{H}_{2} \mathrm{O}_{2}\right)$ is equal to $+0.94 \mathrm{~V}$ (Asada \& Takahashi, 1987) in the aqueous solutions and in the presence of the electron donors and protons $\mathrm{O}_{2}{ }^{--}$can react as a good oxidant producing $\mathrm{H}_{2} \mathrm{O}_{2}$. Ascorbate, quinols, glutathione, and so on can be such donors. In the absence of donors, the dismutation of $\mathrm{O}_{2}{ }^{-}$ is the main reaction of $\mathrm{H}_{2} \mathrm{O}_{2}$ production. In the cell, $\mathrm{H}_{2} \mathrm{O}_{2}$ can also be produced by twoelectron oxidases such as glycolate, glucose, amino and sulfite oxidases, which oxidize these substrates by dioxygen directly (Byczkowsky \& Gessener, 1988).

The lowest $\mathrm{pK}_{\mathrm{a}}$ value of $\mathrm{H}_{2} \mathrm{O}_{2}$ is 11.8 , and under physiological pHs $\mathrm{H}_{2} \mathrm{O}_{2}$ exists mostly in the neutral form. The properties of $\mathrm{H}_{2} \mathrm{O}_{2}$ in the aqueous solutions are determined mainly by hydrogen bonds between water and $\mathrm{H}_{2} \mathrm{O}_{2}$ molecules. These bonds can prevent transfer of $\mathrm{H}_{2} \mathrm{O}_{2}$ molecules from the aqueous solution to the hydrophobic solvent in spite of their neutral form. The value of $\mathrm{E}_{0}^{\prime}\left(\mathrm{H}_{2} \mathrm{O}_{2} / \mathrm{H}_{2} \mathrm{O}\right)$ in aqueous solutions is equal to $+1.3 \mathrm{~V}$ vs. NHE, and in acidic solutions $\mathrm{H}_{2} \mathrm{O}_{2}$ is one of the most powerful chemical oxidizers. The reduction of $\mathrm{H}_{2} \mathrm{O}_{2}$ to water requires the breaking of $\mathrm{O}-\mathrm{O}$ bond, and under physiological conditions the main target of oxidizing action of $\mathrm{H}_{2} \mathrm{O}_{2}$ are the reduced sulfhydril groups of biomolecules.

Hydroxyl radical, $\mathrm{OH}^{\bullet}$, the most destructive ROS, can be produced in cells in the reaction of $\mathrm{H}_{2} \mathrm{O}_{2}$ molecule decomposition, which is catalyzed by metal. The reaction in which the reductant of $\mathrm{H}_{2} \mathrm{O}_{2}$ is ferrous iron terms as the Fenton reaction (Reaction 2).

$$
\mathrm{H}_{2} \mathrm{O}_{2}+\mathrm{Fe}^{2+} \rightarrow \mathrm{Fe}^{3+}+\mathrm{OH}^{-}+\mathrm{OH}^{\bullet}
$$


This reaction can also be catalyzed by univalent cuprous ion, which is oxidized to divalent ion. Both the oxidized iron and cuprum can be re-reduced by $\mathrm{O}_{2}{ }^{-}$, and the total reaction of $\mathrm{H}_{2} \mathrm{O}_{2}$ reduction by $\mathrm{O}_{2}{ }^{--}$terms as the Haber-Weiss reaction. The reduction of ferric ion to ferrous can also occur by the reduced cell components, such as ascorbate.

Hydroxyl radical is the penultimate step of dioxygen reduction to water, but this ROS is the strongest oxidant with $\mathrm{E}_{0}^{\prime}\left(\mathrm{OH} \cdot / \mathrm{H}_{2} \mathrm{O}\right)=+2.3 \mathrm{~V}$. Because of high reactivity, $\mathrm{OH}^{\bullet}$ is able to readily oxidize almost all biomolecules at nearly diffusion controlled rates. Therefore $\mathrm{OH} \cdot$ interacts with lipids, proteins and nucleic acids right in the place where it is generated. Since such generation depends on the location of $\mathrm{H}_{2} \mathrm{O}_{2}$ production, as well as the presence of both metals and reductants, all these circumstances determine the site specificity of the destructive effect of $\mathrm{OH}^{\bullet}$ on biomolecules (Asada \& Takahashi, 1987).

The peroxyl radical, $\mathrm{ROO}^{*}$, and hydroperoxide, $\mathrm{ROOH}$, of organic molecule can be considered as long-lived ROS. Their generation usually occurs during the free radical chain reaction known as lipid peroxidation, where they are termed as $\mathrm{LOO}^{\bullet}$ and $\mathrm{LOOH}$. The lipid peroxidation is actually the oxidation of polyunsaturated fatty acid side chains of the membrane phospholipids, and it is initiated by the abstraction of hydrogen atom from the bis-allylic methylene of $\mathrm{LH}$ to produce $\mathrm{L} \cdot$. The abstraction can be executed by perhydroxyl radical as stated above, whereas the role of $\mathrm{O}_{2}{ }^{--}$is usually denied (Bielski et al., 1983), as well as by hydroxyl radical, if the latter does appear in the membrane, and by other ways, e.g. by long-lived oxidized reaction center of PSII (see 2.2.2). Under physiological conditions the most possible reaction of $\mathrm{L}^{\cdot}$ is the reaction with dioxygen, when one active electron from organic radical can occupy one of partially filled antibonding orbitals of dioxygen, producing $\mathrm{LOO}^{*}$. This radical is reactive enough to attack adjacent fatty acid side chain, abstracting hydrogen, producing $\mathrm{LOOH}$ and new $\mathrm{L} \cdot$; and thus propagating the chain oxidation of lipids. ${ }^{1} \mathrm{O}_{2}$, reacting with fatty acid can form $\mathrm{LOOH}$ directly. $\mathrm{LOOH}$ can decompose to highly cytotoxic products, among of which the aldehydes are most dangerous.

\subsection{Production of ROS in chloroplasts}

Mehler observed the oxygen uptake and $\mathrm{H}_{2} \mathrm{O}_{2}$ formation under illumination in broken chloroplasts, i.e. the chloroplasts with destroyed envelope (Mehler, 1951). Later, it was shown that the primary product of $\mathrm{O}_{2}$ reduction in the photosynthetic electron transport chain is the $\mathrm{O}_{2}{ }^{--}$(Allen \& Hall, 1973; Asada et al., 1974). The oxygen reduction rate averages $25 \mu \mathrm{mol} \mathrm{O} 2 \mathrm{mg} \mathrm{Chl}^{-1} \mathrm{~h}^{-1}$ in isolated thylakoids under saturating light intensity (Asada \& Takahashi, 1987; Khorobrykh et al., 2004). Oxygen uptake and $\mathrm{H}_{2} \mathrm{O}_{2}$ formation under illumination of thylakoids is the result of the reactions

$$
\begin{gathered}
2 \mathrm{H}_{2} \mathrm{O}-4 \mathrm{e}^{-} \rightarrow 4 \mathrm{H}^{+}+\mathrm{O}_{2} \text { (release) - water oxidation in PSII } \\
4 \mathrm{O}_{2}+4 \mathrm{e}^{-} \rightarrow 4 \mathrm{O}_{2} \cdot-\text { - dioxygen reduction }
\end{gathered}
$$

and subsequent dismutation of $\mathrm{O}_{2}{ }^{--}$(Reaction 1). Taking into account the peculiarities of this electron flow, namely that the donor and the acceptor are the forms of oxygen, and the fact that an electron does not return back to the place of its donation to PETC, this flow besides "the Mehler reaction" was termed "pseudocyclic electron transport". 


\subsubsection{Production of ROS in chloroplast stroma: mechanism and producers}

\section{Production of superoxide in stroma}

Ferredoxin $(\mathrm{Fd})$, a stromal protein and the electron carrier between PSI and NADP+, has long been regarded as the main reductant of oxygen in the Mehler reaction. The addition of $\mathrm{Fd}$ to the suspension of isolated thylakoids led to an increase of an oxygen consumption rate (Allen, 1975a; Furbank \& Badger, 1983; Ivanov et al., 1980). $\mathrm{E}_{\mathrm{m}}$ for $\mathrm{Fd} / \mathrm{Fd}$ red is $-420 \mathrm{mV}$ that enables the reduced $\mathrm{Fd}\left(\mathrm{Fd}\right.$ red) to reduce $\mathrm{O}_{2}$ to $\mathrm{O}_{2}{ }^{--}$in the water media. The pseudo-first order rate constant of this reacton was found to be in the region $0.07-0.19 \mathrm{~s}^{-1}$ (Golbeck \& Radmer, 1984, Hosein \& Palmer, 1983, Kozuleva et al., 2007). The weak capability of Fdred to reduce $\mathrm{O}_{2}$ is important for function of chloroplasts since Fdred is a key metabolite that is required for many metabolic reactions in chloroplasts, first of all, the reduction of NADP+.

Recently it was shown that oxygen reduction by $\mathrm{Fd}$ is only a part of the total oxygen reduction by PETC (Kozuleva \& Ivanov, 2010). The share of oxygen reduction by Fd was measured to be $40-70 \%$ in the absence and $1-5 \%$ in the presence of $\mathrm{NADP}^{+}$. It means that in vivo oxygen reduction occurs mostly by the membrane-bound components of PETC rather than by Fdred, however the role of Fd can increase if the $\mathrm{NADP}^{+}$supply becomes limited.

It was shown that some stromal flavoenzymes such as ferredoxin-NADP+ oxidoreductase, monodehydroascorbate reductase and glutathion reductase added to thylakoid suspension also can produce $\mathrm{O}_{2}{ }^{--}$(Miyake et al., 1998). The authors have suggested that these enzymes are reduced by Photosystem I (PSI) directly. However in vivo the enzymes have to compete with Fd for electrons from terminal acceptors of PSI at the docking site that is optimized for association with $\mathrm{Fd}$. So this way of oxygen reduction is unlikely under normal conditions.

\section{Production of hydrogen peroxide in stroma}

It is considered that the dismutation of $\mathrm{O}_{2}{ }^{--}$with involvement of SOD is the main producer of $\mathrm{H}_{2} \mathrm{O}_{2}$ in chloroplasts stroma. The production of $\mathrm{H}_{2} \mathrm{O}_{2}$ in stroma through the reduction of $\mathrm{O}_{2}{ }^{--}$by ascorbic acid or by reduced glutathione (GSH) is also possible. However the rate constants for these reactions are $3.3 \times 10^{5} \mathrm{M}^{-1} \mathrm{~s}^{-1}$ (Gotoh \& Niki, 1992) and $10^{2}-10^{3} \mathrm{M}^{-1} \mathrm{~s}^{-1}$ (Winterbourn \& Metodiewa, 1994), respectively, i.e. they are considerably less than that for SOD-catalyzed dismutation, $2 \times 10^{9} \mathrm{M}^{-1} \mathrm{~s}^{-1}$. Fdred was also proposed to produce $\mathrm{H}_{2} \mathrm{O}_{2}$ in the reaction with $\mathrm{O}_{2}{ }^{--}$generated in course of the Mehler reaction (Allen, 1975b). However in vivo $\mathrm{Fdred}$ is involved in a number of reactions and its steady-state concentration is not high, and this way of $\mathrm{H}_{2} \mathrm{O}_{2}$ production in stroma should be unlikely in the case of effective operation of SOD.

\section{Production of hydroxyl radical in stroma}

The main way of $\mathrm{OH}^{\bullet}$ generation is the Fenton reaction (Reaction 2). In chloroplasts stroma there are pools of iron deposited in a redox inactive form. Iron is bound with chelators such as ferritin, the iron storage protein (Theil, 2004), as well as low molecular mass chelators, e.g. nicotianamine (Anderegg \& Ripperger, 1989). The concentration of free iron ions can be increased when the accumulation of the iron either exceeds the chelating ability of chloroplasts or the iron is released from its complex with chelators (Thomas et al., 1985). The authors have suggested that $\mathrm{O}_{2}{ }^{\cdot-}$ can cause the releasing of iron from ferritin. 
The reduced ferredoxin can catalyze the Fenton reaction probably due to it has Fe in its structure (Hosein \& Palmer, 1983; Snyrychova et al., 2006). However as it was noted above, the reduced ferredoxin in chloroplast is effectively used for various metabolic pathways, and its level is not high. So, this way of $\mathrm{OH}^{\bullet}$ generation can be significant only under stress conditions. The production of $\mathrm{OH}^{\bullet}$ also can occur during sulfite oxidation in chloroplasts, and both sulfite radical and hydroxyl radical can initiate oxidative damage of unsaturated lipids and chlorophyll molecules (Pieser et al., 1982).

\subsubsection{Production of ROS in thylakoid membrane: mechanism and producers}

\section{Production of singlet oxygen in thylakoid membrane}

The main route of ${ }^{1} \mathrm{O}_{2}$ generation in thylakoids is the transfer of energy from the chlorophyll in triplet state to molecular oxygen (Neverov \& Krasnovsky Jr., 2004; Rutherford \& KriegerLiszkay, 2001). The main place of the chlorophyll triplet state formation in thylakoids is PSII, presumably a chlorophyll a molecule located on the surface of the pigment-protein complexes and a chlorophyll $a$ molecule of the special pair (P680) (Neverov \& Krasnovsky Jr., 2004). The chlorophyll triplet state and hence $1 \mathrm{O}_{2}$ are usually formed under conditions that are favourable for the charge recombination in $\mathrm{P} 680^{+} \mathrm{Pheo}^{-}$when forward electron transport is very limited (for review see Krieger-Liszkay, 2005), for example when the plastoquinone pool (PQ-pool) becomes over-reduced. This leads to the full reduction of $\mathrm{Q}_{\mathrm{A}}$ and results in a low yield of charge separation due to the electrostatic effect of $\mathrm{QA}^{-}$on the $\mathrm{P}_{680}{ }^{+} \mathrm{Pheo}^{-}$radical pair. This is known as closed PSII however still around $15 \%$ of charge separation occurs at such conditions leading to the formation of the chlorophyll triplet state.

The chlorophyll triplet state formation can occur by a true back reaction through $\mathrm{P}^{6} 80^{+} \mathrm{Pheo}^{-}$ or by a direct (tunneling) recombination (Keren et al., 1995). These processes can happen under normal functional conditions but with a very low rate. The distribution of these two routes is determined by the energy gap between the $\mathrm{P} 680+\mathrm{Pheo}^{-}$radical pair and the $\mathrm{P}_{680}{ }^{+} \mathrm{Q}_{\mathrm{A}^{-}}$radical pair. It was shown that true back reactions with the electron coming back from $\mathrm{Q}_{\mathrm{B}}{ }^{-}$leads to deactivation of some steps in water-oxidizing cycle giving rise to the chlorophyll triplet state formation and ${ }^{1} \mathrm{O}_{2}$ generation (Rutherford \& Inoue, 1984).

It was found that the treatment of plants by some herbicides that are known to bind to $Q_{B}$ site in PSII and to block photosynthetic electron transport results in formation of the chlorophyll triplet state and ${ }^{1} \mathrm{O}_{2}$ that finally leads to death of plants (Krieger-Liszkay \& Rutherford, 1998).

\section{Production of superoxide in thylakoid membrane}

As had been repeatedly proposed $\mathrm{O}_{2}{ }^{--}$can be generated within thylakoid membrane (Kruk et al., 2003; Mubarakshina et al., 2006; Takahashi \& Asada, 1988) and the first direct evidence was recently obtained using detectors of $\mathrm{O}_{2}{ }^{--}$with different lipophilicity (Kozuleva et al., 2011).

PSI. Traditionally it was supposed that the components of acceptor side of PSI, which have highly negative $\mathrm{E}_{\mathrm{m}}$ values are the main reductants of oxygen. $\mathrm{O}_{2}{ }^{\cdot-}$ production can possibly occur under oxidation by oxygen of the FeS centers $\mathrm{F}_{\mathrm{A}}$ and $\mathrm{F}_{\mathrm{B}}$, which are located in PsaC subunit of PSI exposed to stroma. This $\mathrm{O}_{2}{ }^{--}$production would occur outside the thylakoid membrane. The media within thylakoid membrane has low permittivity where $\mathrm{E}_{\mathrm{m}}$ of $\mathrm{O}_{2} / \mathrm{O}_{2}{ }^{\cdot-}$ pair could be approximately $-600 \mathrm{mV}$ (see 2.1). The components of PSI that are 
situated below the surface of the membrane, phylloquinone $A_{1}$ and the FeS cluster $F_{X}$, have $\mathrm{E}_{\mathrm{m}}$ values $-820 \mathrm{mV}$ and $-730 \mathrm{mV}$, respectively (Brettel \& Leibl, 2001). Thus the reduction of $\mathrm{O}_{2}$ by these centers is thermodynamically allowed.

PSII. The $\mathrm{O}_{2}{ }^{--}$generation in PSII has been also shown (Ananyev et al., 1994). However oxygen reduction in this photosystem can achieve only about 1-1.5 $\mu \mathrm{mol} \mathrm{O}_{2} \mathrm{mg} \mathrm{Chl}^{-1} \mathrm{~h}^{-1}$ at physiological pHs (Khorobrykh et al., 2002). In PSII thermodynamically only $\mathrm{Pheo}^{-}\left(\mathrm{E}_{\mathrm{m}}\right.$ of $\mathrm{Pheo} / \mathrm{Pheo}^{-}$is $-610 \mathrm{mV}$ ) is able to reduce $\mathrm{O}_{2}$ to $\mathrm{O}_{2}{ }^{--}$. However under normal functional conditions fast electron transfer from $\mathrm{Pheo}^{-}$to $\mathrm{Q}_{\mathrm{A}^{-}}$(300-500 ps (Dekker \& Grondelle, 2000)) prevents the electron transfer from $\mathrm{Pheo}^{-}$to $\mathrm{O}_{2}$. If $\mathrm{Q}_{\mathrm{A}^{-}}$is fully reduced (e.g. under strong stress conditions) this process likely can occur. It is discussed in the literature (Bondarava et al., 2010; Pospíšil, 2011) that other components of PSII such as $Q_{A^{-}}\left(E_{m}\right.$ of $Q_{A} / Q_{A^{-}}$is $-80 \mathrm{mV}$ (Krieger et al., 1995)) and low-potential form of cytochrome $b_{559}\left(\mathrm{E}_{\mathrm{m}}\right.$ is $0-80 \mathrm{mV}$ (Stewart \& Brudvig, 1998)) can reduce molecular oxygen. However these processes are less favorable thermodynamically and probably do not occur under normal functional conditions.

The plastoquinone pool. Plastoquinone (PQ) is the mobile electron carrier between PS II and cytochrome $b_{6} / f$ complexes in the thylakoid lipid bilayer phase and it simultaneously transfers the protons across the thylakoid membrane. TKhorobrykh \& Ivanov (2002) provided the evidences of the involvement of the PQ-pool in the process of oxygen reduction. Using the inhibitor of the plastoquinol oxidation by cytochrome $b_{6} / f$ complexes, dinitrophenylether of 2-iodo-4-nitrothymol (DNP-INT), the rate of oxygen uptake was measured to be $9-10 \mu \mathrm{mol} \mathrm{O}_{2} \mathrm{mg} \mathrm{Chl}^{-1} \mathrm{~h}^{-1}$ at $\mathrm{pHs}$ higher than 6.5. It was shown that in the course of oxygen reduction in the PQ-pool, $\mathrm{O}_{2}{ }^{\cdot-}$ was produced. Thermodynamical analysis of the data revealed that only plastosemiquinone $\left(\mathrm{PQ}^{\cdot-}\right)\left(\mathrm{E}_{\mathrm{m}}\right.$ of $\mathrm{PQ} / \mathrm{PQ}^{--}$is $\left.-170 \mathrm{mV}\right)$ in the PQ-pool could reduce $\mathrm{O}_{2}$ to $\mathrm{O}_{2} \cdot-$ (Reaction 5).

$$
\mathrm{PQ} \cdot-+\mathrm{O}_{2} \rightarrow \mathrm{PQ}+\mathrm{O}_{2} \cdot-
$$

It was proposed that the Q-cycle operation eliminates an appearance of long-lived PQ ${ }^{--}$in the plastoquinol-oxidizing site (Osyczka et al., 2004). However the free PQ•- can be produced in the reaction of plastoquinone/plastoquinol disproportionation (Rich, 1985) and thus the $\mathrm{PQ} \cdot{ }^{\cdot-}$ can reduce oxygen to $\mathrm{O}_{2}{ }^{\cdot-}$ under normal functional conditions. It was estimated that the product of the free $\mathrm{PQ}^{*-}$ concentration and the rate constant of the reaction between semiquinone and $\mathrm{O}_{2}$ for quinones with $\mathrm{E}_{\mathrm{m}}$ values close to those of $\mathrm{PQ} / \mathrm{PQ}^{--}$, is very similar to the experimentally observed rates of oxygen reduction in the presence of DNP-INT (Mubarakshina \& Ivanov, 2010). Moreover the detailed consideration of this process leads to a conclusion that the reaction between $\mathrm{PQ}^{\cdot-}$ and $\mathrm{O}_{2}$ proceeds at the membrane-water interface.

PTOX. Plastid terminal oxidase (PTOX) is the enzyme that oxidizes plastoquinol and reduces oxygen to water thus it is involved in chlororespiratory and play important role in many processes under stress conditions (for review see Nixon \& Rich, 2006). Using Tobacco plants with over-expressing of PTOX it was proposed that PTOX also can reduce dioxygen to $\mathrm{O}_{2}{ }^{\bullet-}$ (Heyno et al., 2009). However under normal functional conditions this process (even if occurs) should not give the essential contribution to the overall generation of $\mathrm{O}_{2}{ }^{--}$in PETC taking into account that the quantity of PTOX per PSII is $\sim 1 \%$ only (Andersson \& Nordlund, 1999; Lennon et al., 2003). 


\section{Production of hydrogen peroxide in thylakoid membrane}

Spontaneous dismutation of $\mathrm{O}_{2}{ }^{--}$in the thylakoid membrane should be very low owing to a strong electrostatic repulsion in the membrane interior with low permittivity. However it has been found that $\mathrm{H}_{2} \mathrm{O}_{2}$ is produced within the membrane with significant rate and the production increases with an increase of light intensity (Mubarakshina et al., 2006). On the basic of the data presented in (Ivanov et al., 2007; Khorobrykh et al., 2004; Mubarakshina et al., 2006) it was proposed that $\mathrm{H}_{2} \mathrm{O}_{2}$ within thylakoid membrane is produced due to the reduction of $\mathrm{O}_{2}{ }^{\cdot-}$ by plastoquinol (Reaction 6) (for review see Mubarakshina \& Ivanov, 2010).

$$
\mathrm{PQH}_{2}+\mathrm{O}_{2} \cdot-\rightarrow \mathrm{PQ}^{\cdot-}+\mathrm{H}_{2} \mathrm{O}_{2}
$$

$\mathrm{H}_{2} \mathrm{O}_{2}$ can also be produced at PSII donor and acceptor sides. At the acceptor side, $\mathrm{H}_{2} \mathrm{O}_{2}$ can be formed outside thylakoids by the dismutation of $\mathrm{O}_{2}{ }^{-}{ }^{-}$produced within membrane (Arato et al., 2004; Khorobrykh et al., 2002; Klimov et al., 1993) or inside the membrane by the interaction of $\mathrm{O}_{2}{ }^{--}$with non-heme iron of PSII (Pospíšil et al., 2004). At the donor side $\mathrm{H}_{2} \mathrm{O}_{2}$ can be formed as an intermediate during water oxidizing cycle operation if this cycle is seriously disrupted (Ananyev et al., 1992; Hillier \& Wydrzynski, 1993). Thus $\mathrm{H}_{2} \mathrm{O}_{2}$ production at PSII donor and acceptor sides should be largely neglected under normal conditions.

\section{Production of hydroxyl radical in thylakoid membrane}

The various treatments of isolated PSII particles can lead to hydroxyl radical generation (Arato et al., 2004; Pospíšil et al., 2004). Production of hydroxyl radical by PSII is limited under normal functional conditions unlike under the strong stress conditions. It was suggested that in PSI the reduced $\mathrm{F}_{\mathrm{A}}$ and $\mathrm{F}_{\mathrm{B}}$ can catalyze the Fenton's reaction and form $\mathrm{OH}$ • (Snyrychova et al., 2006). The presence of effective electron acceptors from PSI such as methylviologen (Snyrychova et al., 2006) and probably Fd and NADP+, results in a decrease of $\mathrm{OH}^{\bullet}$ generation. So in vivo the production of $\mathrm{OH} \cdot$ by PSI would be minor.

\section{Production of organic peroxides (ROOH) in thylakoid membrane}

It was shown that oxygen uptake in the PSII particles at $\mathrm{pH}$ above 8 and after the Tris treatment was not the result of oxygen reduction to $\mathrm{O}_{2}{ }^{--}$only (Khorobrykh et al., 2002). These conditions can lead to destruction of the water-oxidizing complex and it was proposed that this can result in the formation of long-lived $\mathrm{P}_{680^{+}}$, which can oxidize the close lipids. These lipids can react with oxygen producing the lipid peroxides and thus increasing the oxygen uptake. Using the fluorescent probe Spy-HP it has been recently shown that organic peroxides $(\mathrm{ROOH})$ are produced in PSII membranes when the function of the water-oxidizing complex is disrupted (Khorobrykh et al., accepted).

\subsection{Negative effects of ROS in chloroplasts. ROS scavenging systems as the part of chloroplast metabolism}

\subsubsection{Destructive action of ROS in chloroplasts}

The destructive action of ROS in chloroplasts as well as in other parts of the cell is targeted on proteins, nucleic acids and lipids, which can lose their specific functions even due to small changes in their structure after interaction with ROS. Chloroplasts contain own 
genome represented by the DNA with 110-120 genes, accompanied by own system of the protein biosynthesis, including RNA and ribosomes (Cui et al., 2006). It is interesting that in every chloroplast there are a few tens of genome copies, and this may be an adaptation to the existence under conditions of continuous ROS production by PETC. OH ${ }^{*}$ is considered as the main ROS injuring DNA. It preferably attacks the thimines and cytosines, and in a less extent, adenines, guanines, and the rest of desoxyribose (Cadet et al., 1999). $\mathrm{O}_{2}{ }^{\bullet-}$ has weaker effects on the DNA, and attacks preferably guanines. Since chloroplast genome contains the genes coding some components of PETC, the breakdown of the operation of such genes can affect the normal electron transfer, and the modified PETC in its turn can increase the production of $\mathrm{O}_{2}{ }^{\bullet-}$. In stroma, a toxic $\mathrm{O}_{2}{ }^{--}$action is aimed mostly at hemecontaining enzymes, such as peroxidases (Asada, 1994). In the thylakoid membrane, perhydroxyl radical, can initiate lipid peroxidation that leads to disturbing the membrane structure and its functions, such as barrier, transport, maintenance of the membrane proteins, and so on.

The damaging effect of $\mathrm{H}_{2} \mathrm{O}_{2}$ on the genome is determined by the production of $\mathrm{OH} \bullet$ in the vicinity of DNA. More specific effect of $\mathrm{H}_{2} \mathrm{O}_{2}$ in chloroplasts is the inhibition of photosynthesis. It was found that $\mathrm{H}_{2} \mathrm{O}_{2}$ inhibits the photosynthesis in intact chloroplasts with a half-inhibition at $10 \mu \mathrm{M}$ (Kaiser, 1976). Electron transfer through PETC is rather resistant to $\mathrm{H}_{2} \mathrm{O}_{2}$, and the photosynthesis inhibition in the presence of $\mathrm{H}_{2} \mathrm{O}_{2}$ occurs due to oxidation of thiol groups of enzymes involved in carbon fixation cycle (Charles \& Halliwell, 1980; Kaiser, 1979). It can be calculated that in chloroplasts $10 \mu \mathrm{M} \mathrm{H}_{2} \mathrm{O}_{2}$ can arise during less than for 1 min under usual photosynthesis rates even if only $1 \%$ of electrons are transferred to $\mathrm{O}_{2}$. The survival of the chloroplast is provided by the protective (antioxidant) system, which is very active in chloroplasts (see further).

${ }^{1} \mathrm{O}_{2}$ being produced in PSII interacts mainly with D1 protein of the core complex of PSII reaction center (Aro et al., 1993; Trebst et al., 2002). This process possibly explains the very high rate of the replacement of D1 by newly synthesized proteins at high light intensity. It may be noted that the PSII activity can also be destroyed not only by ${ }^{1} \mathrm{O}_{2}$ produced in PSII but also by ROS produced in PSI (Krieger-Liszkay et al., 2011; Tjus et al., 2001).

\subsubsection{Mechanisms and components of ROS scavenging reactions in stroma and in the thylakoid membrane}

Chloroplasts of the leaf cells are the building sites of the plant. Since potentially harmful ROS are continuously produced in chloroplasts in the light, these organelles are supplied with an efficient system of ROS scavenging. This system may be divided into stromal and membrane parts, however, these parts are connected by common metabolites and operate jointly to maintain chloroplast function. Averaged $\mathrm{O}_{2}$ concentration in chloroplasts under illumination does not estimably differ from the one in the dark owing to a fast equilibration of new $\mathrm{O}_{2}$ molecules in the water phase (Ligeza et al., 1998). The quasi-stationary $\mathrm{O}_{2}$ concentration in the thylakoid membrane in the light can be higher than in other compartments of a chloroplast, due to the production of $\mathrm{O}_{2}$ molecules in water-oxidizing complex. Futhemore the $\mathrm{O}_{2}$ concentration in hydrophobic media is approximately ten times higher than in water. Taking into account the primary generation of ROS by the membrane components, the thylakoid membrane requires particularly strong protection. 


\subsubsection{Stromal defense system}

Superoxide dismutase. SODs are the water-soluble proteins. The main chloroplast isoform of SOD in all plants is CuZn-SOD, and some plants also contain Fe-SOD in stroma (Kurepa et al., 1997). Immunogold labeling of the chloroplastic CuZn-SOD revealed that the enzyme is mostly concentrated, almost $70 \%$ of its total amount, in 5-nm layer in the vicinity of the thylakoid membrane surface (Ogawa et al., 1995). Authors stated its local concentration in this layer as about $1 \mathrm{mM}$. Thus SOD prevents the incoming of $\mathrm{O}_{2} \cdot{ }^{-}$from the membrane to stroma. SOD scavenges $\mathrm{O}_{2}{ }^{--}$also in the bulk of stroma, where $\mathrm{O}_{2}{ }^{--}$can emerge due to oxidation of Fdred or some other enzymes by oxygen.

Ascorbate and ascorbate peroxidase. The concentration of ascorbate in chloroplasts is very high, achieving $10-50 \mathrm{mM}$ (for review see Smirnoff, 2000), and even about $300 \mathrm{mM}$ in alpine plants (Streb et al., 1997). Ascorbate can act as an effective quencher of $\mathrm{O}_{2}{ }^{--}$with a high rate constant. Moreover ascorbate is involved in regeneration of the a-tocopherol radicals formed during detoxification of lipid peroxide radicals. The scavenging of $\mathrm{H}_{2} \mathrm{O}_{2}$ in chloroplasts is performed by ascorbate peroxidase (APX), which catalyzes the reaction of $\mathrm{H}_{2} \mathrm{O}_{2}$ with ascorbate. Catalase was not found in chloroplasts, although the low catalase activity of thylakoids and some stromal components is not ruled out. Having more low value of $\mathrm{K}_{\mathrm{m}}\left(\mathrm{H}_{2} \mathrm{O}_{2}\right)$ as compared with catalase, $80 \mu \mathrm{M}$ vs. $25 \mathrm{mM}$, APX can provide more low $\mathrm{H}_{2} \mathrm{O}_{2}$ concentration; and this is important, taking into account the inhibitory effect of $\mathrm{H}_{2} \mathrm{O}_{2}$ on the Calvin cycle enzymes (see 2.3.1). The reaction, which is catalyzed by APX has a high rate constant, $10^{7} \mathrm{M}^{-1} \mathrm{~s}^{-1}$. Chloroplasts contain APX in two isofoms, thylakoid-bound and soluble stromal ones (Miyake \& Asada, 1992). Both APXs are highly specific to ascorbate as the electron donor, and they are promptly inactivated, during $10 \mathrm{~s}$, in its absence (Nakano \& Asada, 1987). These peroxidases form two defending lines to protect stromal components from $\mathrm{H}_{2} \mathrm{O}_{2}$.

Glutathione and glutathione peroxidase. The reduced form of glutathione (GSH) plays an important role in the stabilization of many stromal enzymes. For the antioxidant function it is important that it serves as a substrate for dehydroascorbate reductase. GSH is able to react directly with ROS including $\mathrm{H}_{2} \mathrm{O}_{2}$ (Dalton et al., 1986), hydroxyl radical (Smirnoff \& Cumbes, 1989) and even ${ }^{1} \mathrm{O}_{2}$ (Devasagayam et al., 1991). Chloroplasts also contain phospholipid hydroperoxide-scavenging glutathione peroxidase (Eshdat et al., 1997) that may be involved in the reduction of lipid peroxide of thylakoid membranes to its alcohol, suppressing the chain oxidation of thylakoid phospholipids. This glutathione peroxidase may be considered as the part of the membrane defense system.

Osmolytes. Osmolytes are the group of metabolites that decrease water potential inside the cell and prevent intracellular water loss. This group includes soluble sugars, glycine, betaine, proline etc. The antioxidant capacity of proline is the result of its ability to quench ${ }^{1} \mathrm{O}_{2}$ and scavenge $\mathrm{OH} \cdot$ (Matysik et al., 2002). Recently it was shown that synthesis of proline occurs, at least partly, in chloroplasts (Székely et al., 2008) where proline can execute the antioxidant function and protect both the membranes against lipid peroxidation and the stromal enzymes against desactivation.

Some soluble sugars were recently recognized as antioxidants (for review see BolouriMoghaddam et al., 2010). Addition of mannitol to thylakoid suspension resulted in decrease of $\mathrm{OH}^{\bullet}$ production, and the transgenic tobacco plants with enhanced mannitol production 
targeted to the chloroplast had the increased $\mathrm{OH}^{\bullet}$ scavenging capacity (Shen et al., 1997). The mutants of Arabidopsis with overexpressed enzymes providing the elevated concentration of galactinol and raffinose in leaves were more resistant to oxidative stress caused by methylviologen treatment than wild-type plants (Nishizawa et al., 2008). The authors concluded that antioxidant capacity of these sugars could be explained by their reaction with $\mathrm{OH}^{\cdot}$ (the rate constants were measured as $7.8 \times 10^{9} \mathrm{M}^{-1} \mathrm{~s}^{-1}$ and $8.4 \times 10^{9} \mathrm{M}^{-1} \mathrm{~s}^{-1}$ for galactinol and raffinose, respectively).

Peroxiredoxins. Peroxiredoxins (PRXs) are identified as antioxidant enzymes for detoxification of $\mathrm{H}_{2} \mathrm{O}_{2}$ (for review see Dietz et al., 2006). Furthermore it was found that PRXs can also detoxify alkyl hydroperoxides and peroxinitrite, and probably can modulate oxolipid-dependent and NO-related signalling (Baier and Dietz, 2005; Rhee et al., 2005; Sakamoto et al., 2003). PRXs are 17-22 kDa enzymes that possess N-terminal cysteine residue(s) responsible for peroxidase activity. Four PRXs that are targeted to chloroplasts were identified in Arabidopsis: 2-cysteine (2-Cys) PRXs dimeric and oligomeric forms, PRX Q and PRX II E (Dietz et al., 2006). 2-Cys PRXs and PRX Q are associated with thylakoid membrane components while PRX II E has been identified as stromal enzyme. PRXs become oxidized after reaction with $\mathrm{H}_{2} \mathrm{O}_{2}$. Re-activation of oxidized PRXs in chloroplasts occurs via action of thioredoxin and thioredoxin-like proteins (Broin et al., 2002).

Flavonoids. Flavonoids were found to perform an antioxidant function in tissues exposed to a wide range of environmental stressors (Babu et al., 2003; Reuber et al., 1996). It has been recently assumed that antioxidant activity of flavonoids outperforms that of well-known antioxidants, such as ascorbate and a-tocopherol (Hernández et al., 2008). Flavonoids effectively scavenge the free radicals (for review see Rice-Evans et al., 1996). This can occur due to their ability to quench unpaired electrons of radicals, e.g. $\mathrm{O}_{2}{ }^{--}$(Sichel et al., 1991). It was also shown that flavonoids situated in chloroplasts can scavenge ${ }^{1} \mathrm{O}_{2}$ (Agati et al., 2007). Flavonoids include the substances with different lipophilicity, and thus perform their antioxidant functions in stroma as well as in the membrane.

\subsubsection{Membrane defense system}

Vitamin E. Vitamin E is the class of lipophilic compounds ( $\alpha-, \beta-, \gamma^{-}$and $\delta$-tocopherols (Tocs); $\alpha^{-}, \beta-, \gamma^{-}$and $\delta$ - tocotrienols and their derivatives). Vitamin $\mathrm{E}$ is synthesized in the plastid envelope and is stored in plastoglobuli (for review see Lichtenthaler, 2007). The greatest amount of Tocs is found in the membranes of chloroplasts (including thylakoid membranes) where they execute the antioxidant function.

Vitamin E can react with almost all ROS. It can reduce $\mathrm{O}_{2}{ }^{--}$with the rate constant of $10^{6} \mathrm{M}^{-1} \mathrm{~S}^{-1}$ (Polle \& Rennenberg, 1994). It was shown that vitamin $\mathrm{E}$ has scavenging activity against $\mathrm{OH}^{\bullet}$ (Wang \& Jiao, 2000) and can decompose $\mathrm{H}_{2} \mathrm{O}_{2}$ (Srivastava et al., 1983). a-Toc protects PSII from oxidative damage. Trebst et al. (2002) showed that inhibition of Toc biosynthesis in Chlamydomonas resulted in a stimulation of light-induced loss of PSII activity and D1 protein degradation. This implies that Toc can come close to the site of ${ }^{1} \mathrm{O}_{2}$ generation in the reaction center of PSII. The rate constants for ${ }^{1} \mathrm{O}_{2}$ quenching by different Tocs are appr. $0.13-3.13 \times 10^{8} \mathrm{M}^{-1} \mathrm{~s}^{-1}$ in organic solvents (Gruszka et al., 2008), so Tocs can be the effective scavengers of ${ }^{1} \mathrm{O}_{2}$ within the membrane. It is also possible that a-Tocs can protect the $\beta$-carotene molecules in PSII, thereby preventing the PSII damage (Havaux et al., 2005). Tocs can reduce fatty acyl peroxy radicals, thus terminating lipid peroxidation chain 
reactions (Polle \& Rennenberg, 1994). The regeneration of Tocs occurs with involving of water-soluble antioxidants. For example, formation of a-Toc from a-Toc quinone has been reported to take place in vitro in the presence of ascorbate (Gruszka et al., 2008).

Carotenoids. There are two major types of carotenoids: the hydrocarbon class, or carotenes, and the oxygenated (alcoholic) class, or xanthophylls. Carotenoids can efficiently quench the dangerous triplet state of chlorophylls that is the origin of the ${ }^{1} \mathrm{O}_{2}$ (Cogdell et al., 2000). This mostly occurs in the antenna system (Mozzo et al., 2008) but not in the reaction center. It is also known, that carotenoids, namely $\beta$-carotene, can quench ${ }^{1} \mathrm{O}_{2}$ directly (Foote and Denny, 1968). It was shown that a lack of such carotenoids as zeaxanthin and lutein leads to ${ }^{1} \mathrm{O}_{2}$ accumulation in thylakoids (Alboresi et al., 2011).

Plastoquinone. Plastoquinone (PQ-9), which as the chemical substance is the isoprenoid prenyllipid, is present in thylakoid membranes, chloroplast envelope and osmiophilic plastoglobuli of the stroma (Lichtenthaler, 2007). Plastoglobuli represent the storage compartments for plastoquinone, mainly in its reduced state. In the thylakoid membrane, PQ-pool maintained in the reduced state can execute antioxidant function, preventing membrane lipid peroxidation and pigment bleaching (Hundal et al., 1995). Furthermore it was shown that in vitro plastoquinol has an antioxidant activity similar or even higher than that of tocopherols (Kruk et al., 1994, 1997). It was also found that the added quinones can quench the excited states of chlorophyll molecules (Rajagopal et al., 2003), thus inhibiting the $1 \mathrm{O}_{2}$ generation. Moreover plastoquinone can also directly scavenge ${ }^{1} \mathrm{O}_{2}$ that is produced by the reaction center triplet chlorophyll of PSII (Kruk \& Trebst, 2008; Yadav et al., 2010). It is very possible that plastoquinol effectively scavenges $\mathrm{O}_{2}{ }^{--}$and perhydroxyls in thylakoid membrane (Reaction 6) (for review see Mubarakshina \& Ivanov, 2010). These reactions are the mechanisms by which the PQ-pool can prevent membrane lipid peroxidation. It is known that even in the dark the PQ-pool can be in the reduced state owing to operation of the Ndh complex. This can provide the protective function of the PQ-pool in the membrane if ROS are produced under stress in the dark. It was found that the extent of the PQ-pool reduction in the dark increased upon heat stress, and this was considered as involvement of the Ndh complex in the defense system (Sazanov et al., 1998). Thus it is possible to assume that the higher amount of plastoquinone than of other components of PETC is needed in order to execute the antioxidant function rather than the electron carrier function.

\subsection{Role of reaction of oxygen with chloroplast components in the constructive metabolism}

\subsubsection{Photorespiration}

Photorespiration is a pathway of oxidative carbon metabolism which resulted from oxygenase activity of ribulose-1,5-bisphosphate carboxylase/oxygenase (RubisCO) (for review see Maurino \& Peterhansel, 2010). Photorespiration cycle starts in chloroplasts from the reaction of ribulose-1,5-bisphosphate with $\mathrm{O}_{2}$ molecule. As the result 3phosphoglycerate and 2-phosphoglycolate are produced. The latter is dephosphorylated to glycolate, a toxic molecule. The following reactions of glycolate metabolism lead to a recover of 3-phosphoglycerate and occur in peroxisomes, mitochondria, cytosol and, finally, in chloroplasts again. At current atmospheric levels of $\mathrm{CO}_{2}$ and $\mathrm{O}_{2}$, photorespiration in $\mathrm{C}_{3}$ plants dissipates $25 \%$ of the carbon fixed during $\mathrm{CO}_{2}$ assimilation (Sharkey, 1988). 
Photorespiration is required for all photosynthetic organisms, including cyanobacteria (Eisenhut et al., 2008) and even higher plants with $\mathrm{C}_{4}$-type of photosynthesis (Zelitch et al., 2008). As a part of chloroplast metabolism, photorespiration can be considered as one of the sinks for the excess of the energetic equivalents such as ATP and NAD(P)H under different stresses (for review see Wingler et al., 2000). Photorespiration operates also as a safety valve protecting PETC from over-reduction, and thus preventing the generation of ROS by components of PETC. Furthermore it can prevent the ROS formation in stroma by using $\mathrm{NAD}(\mathrm{P}) \mathrm{H}$ itself, since $\mathrm{NAD}(\mathrm{P}) \mathrm{H}$ can to some extent spontaneously reduce oxygen to $\mathrm{O}_{2}{ }^{\cdot-}$ giving $\mathrm{H}_{2} \mathrm{O}_{2}$.

\subsubsection{The electron transport to oxygen in PETC and ATP production for chloroplast metabolism}

Oxygen reduction in PETC was mainly considered as an important part of the chloroplasts metabolism due to possibility of additional ATP synthesis coupled with this process (Badger, 1985; Heber, 1973). There were calculations of ATP synthesis coupled with $\mathrm{O}_{2}$ reduction from the total ATP synthesis during simultaneous reductions of both $\mathrm{NADP}^{+}$and $\mathrm{O}_{2}$ (Furbank \& Badger, 1983; Ivanov et al., 1980; Robinson \& Gibbs, 1982). Observed in some studies lower efficiency for ATP production of the pseudocyclic electron transport as compare with the efficiency of the non-cyclic electron transport in $\mathrm{C}_{3^{-}}$(Woo, 1983) as well as in $\mathrm{C}_{4}$-plants (Ivanov \& Edwards, 2000) can be probably explained now as a result of the use of the protons bound by $\mathrm{PQH}_{2}$ not only for the $\Delta \mathrm{pH}$ formation across the thylakoid membrane but also for the reduction of $\mathrm{O}_{2}{ }^{--}$to $\mathrm{H}_{2} \mathrm{O}_{2}$ in the membrane (see 2.2.2).

The Mehler reaction is now considered as a part of so called water-water cycle (WWC). The last term was proposed by Asada, who described the reactions involved in WWC in the fullest detail (Asada, 1999). Briefly, WWC includes the transport of the electrons from water to oxygen, the $\mathrm{O}_{2}{ }^{-}$- dismutation catalyzed by SOD, the reduction of $\mathrm{H}_{2} \mathrm{O}_{2}$ by ascorbate with involvement of APX (see 2.3.2.1), followed by the reduction of monodehydroascorbate (MDHA) appearing in the latter reaction to ascorbate by the electrons from PETC (i.e. ultimately from water). The reduction of $\mathrm{O}_{2}$ in PETC is the slowest reaction in WWC, while other reactions proceed with almost diffusion-controlled rates. The latter ensures the minimal accumulation of $\mathrm{O}_{2}{ }^{--}$and $\mathrm{H}_{2} \mathrm{O}_{2}$, preventing their interaction with the target molecules in stroma. The equal amounts of electrons reduce $\mathrm{O}_{2}$ and MDHA in WWC. Thus WWC constitutes in the total photosynthetic electron flow the double of what is the electron transport to $\mathrm{O}_{2}$ itself. The reduction of MDHA can deprive the Calvin cycle of electrons, i.e. can cease the photosynthesis. The photosynthesis of the intact chloroplasts was completely suppressed at $\mathrm{H}_{2} \mathrm{O}_{2}$ addition in the light and the $\mathrm{CO}_{2}$ fixation restarted after the $\mathrm{H}_{2} \mathrm{O}_{2}$ was exhausted (Nakano \& Asada, 1980). This result demonstrated that the system of $\mathrm{H}_{2} \mathrm{O}_{2}$ scavenging has priority over the system of $\mathrm{CO}_{2}$ fixation in receiving electrons from PETC; this conclusion was supported in (Backhausen et al., 2000).

It was shown that WWC does play the important role in chloroplasts, and the breakdown of its normal operation negatively influences on the metabolism of these organelles (Rizhsky et al., 2003). This may mainly result from the destructive effects of ROS, but possibly also from the decrease of ATP/NADPH ratio. It is accepted now, that the electron flow to NADP+ provides, the ATP/NADPH of 1.5 owing to Q-cycle operation (Ivanov, 1993). Exactly such ratio is required in order the Calvin cycle reactions to proceed, but ATP is necessary in 
chloroplasts not only for the cycle, but also for biosynthesis of protein and numerous transport processes. The cyclic electron transport around PSI, which can be essential producer of ATP also cannot operate under anaerobic conditions when PETC is overreduced, and the necessary redox poising for this transport is provided by the electron transfer to $\mathrm{O}_{2}$ (Ziem-Hanck \& Heber, 1980).

\subsubsection{Role of electron transfer to oxygen in the protection of PETC from photoinhibiton}

The electron flows involved in WWC besides the ATP production play an important role in the protection of photosynthetic apparatus from photoinhibition under illumination. The excess of photon energy beyond the necessary one to fulfil $\mathrm{CO}_{2}$ assimilation can arise not only in strong light, but also in moderate and even low light when the environmental conditions (the improper temperature, insufficient water supply, high salt concentration, the presence of pollutants, and so on) lead to suppression of the capacity of the photosynthetic apparatus for $\mathrm{CO}_{2}$ assimilation.

WWC and cyclic electron transport are primarily coupled with the proton pumping into the thylakoid lumen, and these protons in the lumen initiate conformational and biochemical changes, which accelerate thermal energy dissipation in antenna and reaction centers (Horton et al., 1996). The pigment apparatus state providing the dissipation of the photon energy into a heat originates due to violaxanthin de-epoxidation to antheraxanthin and zeaxanthin. This reaction, which requires ascorbate, is catalyzed by violaxanthin deepoxidase (VDE) situated at the lumen side of thylakoid membrane; VDE is activated by a decrease of lumen $\mathrm{pH}$ to 5-6 (for review see Demmig-Adams, 1990). Since WWC does not consume ATP, the accumulation of protons in lumen is very fast in the absence of inorganic carbon fixation in $\mathrm{C}_{3}$ - and in $\mathrm{C}_{4}$-plants (Ivanov et al., 1998; Ivanov \& Edwards, 2000). This allows WWC to respond to such changes in light intensity as sunflecks.

The overreduction of the acceptor side of PSII is one of the pre-conditions of photoinhibition initiation, and the electron withdrawal from PETC to $\mathrm{O}_{2}$ and MDHA within WWC also can effectively use the excess of light energy for the electron transfer. This is especially important under limiting supply of $\mathrm{CO}_{2}$. It is known that photoinhibition of PSII owing to overreduction occurs under anaerobic conditions even at rather low light intensity (Park et al., 1996) and is prevented even by low dioxygen concentrations when WWC begins to function. The drain of electrons directly from the PQ-pool to oxygen (see 2.2.2) can be a very important mechanism in protection of PETC from photoinhibiton since the PQ-pool operation is known to be a limiting step of photosynthesis.

\subsection{Signalling pathways under stress conditions.}

The system of signal transfer in plants during stress conditions is a very complicated regulatory mechanism (for recent reviews see Foyer \& Noctor, 2009; Li et al., 2009; Mullineaux, 2009; Suzuki et al., 2011). The biosynthesis of chloroplast proteins are coordinated by both chloroplast and nuclear genomes. Thus the tight cooperation between these two systems is obligatory for the assembly of functionally active chloroplasts. This can only happen due to well-co-ordinated work of regulatory signals coming from nucleus to chloroplasts and from chloroplasts to nucleus. The latter is called the retrograde signalling (Beck, 2005; Chan et al., 2010; Mullineaux \& Karpinski, 2002). 


\subsubsection{ROS as important signalling agents}

Enhanced ROS production under stress conditions is considered to be a signal in order to regulate the cell redox homeostasis. ROS play a key role in the regulation of plant development, programmed cell death and also in biotic and abiotic stress responses (Apel \& Hirt, 2004; Desikan et al., 2001; Mittler et al., 2004). Many of the ${ }^{1} \mathrm{O}_{2}$-responsive genes are different from those activated by $\mathrm{O}_{2} \cdot{ }^{-}$or $\mathrm{H}_{2} \mathrm{O}_{2}$, assuming that the signalling by different ROS occurs via distinct pathways (Laloi et al., 2006; op den Camp et al., 2003) however some ${ }^{1} \mathrm{O}_{2}$-responsive nuclear genes can be activated by other ROS (Anthony et al., 2005; Gadjev et al., 2006). Moreover it has been recently shown that $\mathrm{H}_{2} \mathrm{O}_{2}$ may also either directly or indirectly antagonize ${ }^{1} \mathrm{O}_{2}$-mediated signalling (Baruah et al., 2009; Ledford et al., 2007).

Production of $\mathrm{O}_{2}$ in Arabidopsis thaliana under stress conditions was shown using a specific fluorescent dye (Hideg et al., 2001; op den Camp et al., 2003). Generation of ${ }^{1} \mathrm{O}_{2}$ leads to a rapid change in nuclear gene expression that reveals the transfer of ${ }^{1} \mathrm{O}_{2}$-derived signals from the plastid to the nucleus (Laloi et al. 2006; op den Camp et al. 2003). Using the flu mutant with disturbed chlorophyll biosynthesis it was shown that ${ }^{1} \mathrm{O}_{2}$ forms an integral part of a signalling network that is important not only for stress responses but also for the plant development (Baruah et al., 2009). It was proposed that ${ }^{1} \mathrm{O}_{2}$ accumulation in thylakoids represents a signalling pathway in the early stages of stress acclimation (Alboresi et al., 2011).

A role for $\mathrm{O}_{2}{ }^{\cdot-}$ in retrograde signalling was suggested using gene expression arrays (Scarpeci et al., 2008) and mutations in chloroplastic CuZn-SOD (Rizhsky et al., 2003). The generation of $\mathrm{O}_{2}{ }^{--}$in the absence of $\mathrm{H}_{2} \mathrm{O}_{2}$ accumulation revealed a subset of nuclear encoded genes that are likely to be specific for an $\mathrm{O}_{2}{ }^{--}$-mediated signalling pathway (Scarpeci et al., 2008). In CuZn-SOD mutants, the accumulation of $\mathrm{O}_{2}{ }^{--}$results in activation of chloroplast-encoded genes that is not stimulated by other ROS (Rizhsky et al., 2003).

$\mathrm{H}_{2} \mathrm{O}_{2}$ has been recognized as the ROS causing the largest changes in the levels of gene expression in plants in retrograde signalling (Bechtold et al., 2008; Dat et al., 2000; Fahnenstich et al., 2008; Foyer and Noctor, 2009; Li et al., 2009). $\mathrm{H}_{2} \mathrm{O}_{2}$ possibly induces protein phosphorylation by mitogen-activated protein kinases (MAPKs) (Desikan et al., 1999) which are involved in signalling pathways regulating gene expression (Grant et al., 2000). The reversible redox modulation of Cys residues of the proteins is perhaps the most obvious mechanism for the $\mathrm{H}_{2} \mathrm{O}_{2}$-mediated activation of MAPK pathways. Transcriptomic analyses of Arabidopsis plants have revealed hundreds of $\mathrm{H}_{2} \mathrm{O}_{2}$-responsive genes (Ding et al., 2010; Yun et al., 2010). It was shown that $\mathrm{H}_{2} \mathrm{O}_{2}$ produced inside the chloroplasts can leave the chloroplasts thus escaping the effective antioxidant systems located inside the chloroplast (Mubarakshina et al., 2010). It is possible that the appearance of $\mathrm{H}_{2} \mathrm{O}_{2}$ in cytoplasm can be important for the executing of retrograde signalling mediated by $\mathrm{H}_{2} \mathrm{O}_{2}$.

\subsubsection{Other signalling agents and crosstalk between different signalling pathways and ROS}

Antioxidants can also be the sensors of the stress conditions by the regulation of the level of ROS. It was proposed that the ascorbate content could influence the expression of antioxidative genes in Arabidopsis (Noctor et al., 2000), and APXs located in chloroplasts are 
crucial for photoprotection and signalling (Danna et al., 2003; Kangasjärvi et al., 2008). It was shown that the level of Tocs is also elevated in response to a variety of abiotic stresses, including high-intensity light, drought, toxic metals, and high and low temperatures (Maeda \& DellaPenna, 2007). Furthermore it was suggested that a-Toc may affect intracellular signalling in plant cells by interacting with key components of the signalling cascade (Munné-Bosch et al., 2007).

Thioredoxin, glutathione, peroxiredoxins and glutaredoxins, which contain sulfhydryl groups (-SH), represent a part of the reduction-oxidation signalling network (for more detailed review see Scheibe \& Dietz, 2011, see also Coupe et al., 2006; Fey et al., 2005; Geigenberger et al., 2005; Lindahl \& Kieselbach, 2009). The oxidation of (-SH) groups can occur not only by the interaction between the components having - $\mathrm{SH}$ groups in their structure but also with involvement of $\mathrm{H}_{2} \mathrm{O}_{2}$ since $\mathrm{H}_{2} \mathrm{O}_{2}$ can directly oxidizes $-\mathrm{SH}$ groups (Quesada et al., 1996). In plants two chloroplastic thioredoxins, named thioredoxin $f$ and thioredoxin $m$, were originally identified as light dependent regulators of several carbon metabolism enzymes including Calvin cycle enzymes (Lemaire et al., 2007). It was found that glutathione is involved in the control of gene expression (Dron et al., 1988; Wingate et al., 1988). $\mathrm{H}_{2} \mathrm{O}_{2}$ can be sensed by glutathione peroxidase 3 of Arabidopsis, which modulates activities of phosphatases, protein kinases transcription factors and ion channels involved in abscisic acid signalling pathways (Wang \& Song, 2008).

The PQ-pool can also be considered as both the component of PETC, the redox state of which is an important factor for the redox signalling and the antioxidant, the level of which increases under stress conditions. The treatment of plants by the pathogen-derived elicitor resulted in elevated ROS production, lipid peroxidation and lipoxygenase followed by a significant increase in total plastoquinone level (Maciejewska et al., 2002). High light conditions also lead to a massive accumulation of plastoquinone, preferentially plastoquinol in leaves (Lichtenthaler, 2007; Szymańska \& Kruk, 2010). The changing of the antenna size is one of the main mechanisms of plants acclimate to changes in environmental light conditions. It was revealed that the redox state of the PQ-pool regulates the antenna size of PSII under different light conditions (Escoubas et al., 1995; Fey et al., 2005; Lindahl et al., 1995; Pfannschmidt et al., 1999; Yang et al., 2001). In the works (Frigerio et al., 2007; Morosinotto et al., 2006) it was found that the regulation of the antenna size is carried out by the changing of the antenna proteins quantity at the post-transcriptional level. However the signal from the PQ-pool for the light acclimation has still remained largely unsolved. It was shown that $\mathrm{H}_{2} \mathrm{O}_{2}$ production in the PQ-pool increases with an increase of light intensity (Khorobrykh et al., 2004; Mubarakshina et al., 2006) that is correlated with an increase of the redox state of the PQ-pool. Possibly, $\mathrm{H}_{2} \mathrm{O}_{2}$ can be the best candidate in order to be a signal of the PQ-pool over reduction.

Phytohormones are also the components of cell signalling. The first steps of synthesis of such stress hormones as abscisic, salicylic and jasmonic asids occur in plastids (Vernooij et al., 1994; Wasilewska et al., 2008; Wasternack, 2007) and their influences on the photosynthesis have been demonstrated (Filella et al., 2006; Mateo et al., 2006). However the involvement of phytohormones in chloroplast-to-nucleus signalling is still under debate.

Another component that was shown to be important for the regulation of nuclear genes by chloroplasts is Mg-protoporphyrin (Mg-Proto), the precursor of chlorophyll (Gray, 2003). It was suggested that after illumination, Mg-protoporphyrins can move from chloroplast to 
cytoplasm where they can interact with a signal conductor (von Gromoff et al., 2006). Another possibility is that $\mathrm{Mg}$-protoporphyrins can change the activity of regulatory proteins directly in chloroplasts (for review see Yurina \& Odintsova, 2007). There are no clear evidences about the crosstalk between Mg-protoporphyrin-derived signalling and ROS. It was found that it is unlikely that the accumulation of Mg-Proto is linked to the production of ${ }^{1} \mathrm{O}_{2}$ (Mullineaux, 2009). However it was suggested that light is needed to promote the export of Mg-Proto to the cytosol from the chloroplast (Kropat et al., 1997). Probably this export may involve the co-operation with ROS.

Photosynthesis-derived metabolites can also act as a signal. One of these metabolites is sugar. The regulatory effect of sugars on the expression of nuclear photosynthetic genes and on plant metabolism was established (for review see Gupta \& Kaur, 2005). Both glucose and sucrose were shown to be a signal molecule, and other sugars produced in a number of plant metabolic pathways are also potential signalling agents. The most regulatory effects can be ascribed to glucose (Ramon et al., 2009). Hexokinase, the first enzyme in glucose catabolism can reduce the intracellular ROS levels (Sun et al., 2008). It was shown that mitohondrial hexokinases play a key role as a regulator of ROS levels (Camacho-Pereira et al., 2009). In the work (Bolouri-Moghaddam et al., 2010) it was postulated that chloroplastic hexokinases also can carry out this function. It was shown that the plant with higher levels of hexokinase was more resistant to oxidative stress induced by methylviologen (Sarowar et al., 2008).

\section{Conclusion}

The ways of ROS production and ROS scavenging in chloroplasts are very important for the metabolisms of cell and whole organism. These ways can differ under normal functional conditions and under stress conditions as shown in Figure 1.

As stated here, ROS production can be divided into the stromal part and the membrane part. Probably, the ways of ROS production in different parts of chloroplasts initiate different signalling pathways. The signalling network in chloroplast stroma is widely studied, and many of its characteristics become clear. We also pay the attention to the signalling pathways that may begin in the thylakoid membrane. $\mathrm{H}_{2} \mathrm{O}_{2}$ that is produced in the thylakoid membrane by the reaction of superoxide with plastoquinol can diffuse out of the thylakoid membrane not only to stroma but also to lumen, thus avoiding the antioxidant systems of chloroplast stroma. Some of signal sensors such as thylakoid protein kinases are associated with the thylakoid membrane and the signalling pathway initiated by such kinases may involve $\mathrm{H}_{2} \mathrm{O}_{2}$ produced in the membrane.

The interesting fact is that during stress conditions even such components as osmolytes, flavonoids etc. that have their own functions, also are involved in ROS scavenging. Since the control of ROS level is intrinsically involved in executing their signal roles, the cooperation of the whole system of chloroplast metabolites obviously provides sustaining the chloroplast function under stress conditions.

Although the role of ROS in signalling is commonly accepted now and a lot of studies are focused on the changes in both ROS production under stress conditions and the abundance of the antioxidant and other stress enzymes, the molecular mechanisms of the signalling pathways remain unclear. For example, it is not totally clear, how ROS fulfill signalling 
functions, being inside chloroplasts and how after leaving for cytoplasm. ROS produced inside chloroplast can be the signal for the inside-organelle signalling to regulate the chloroplast genes. If ROS leave the chloroplast and appear in cytoplasm, it can affect the integrated signalling network of the whole cell.
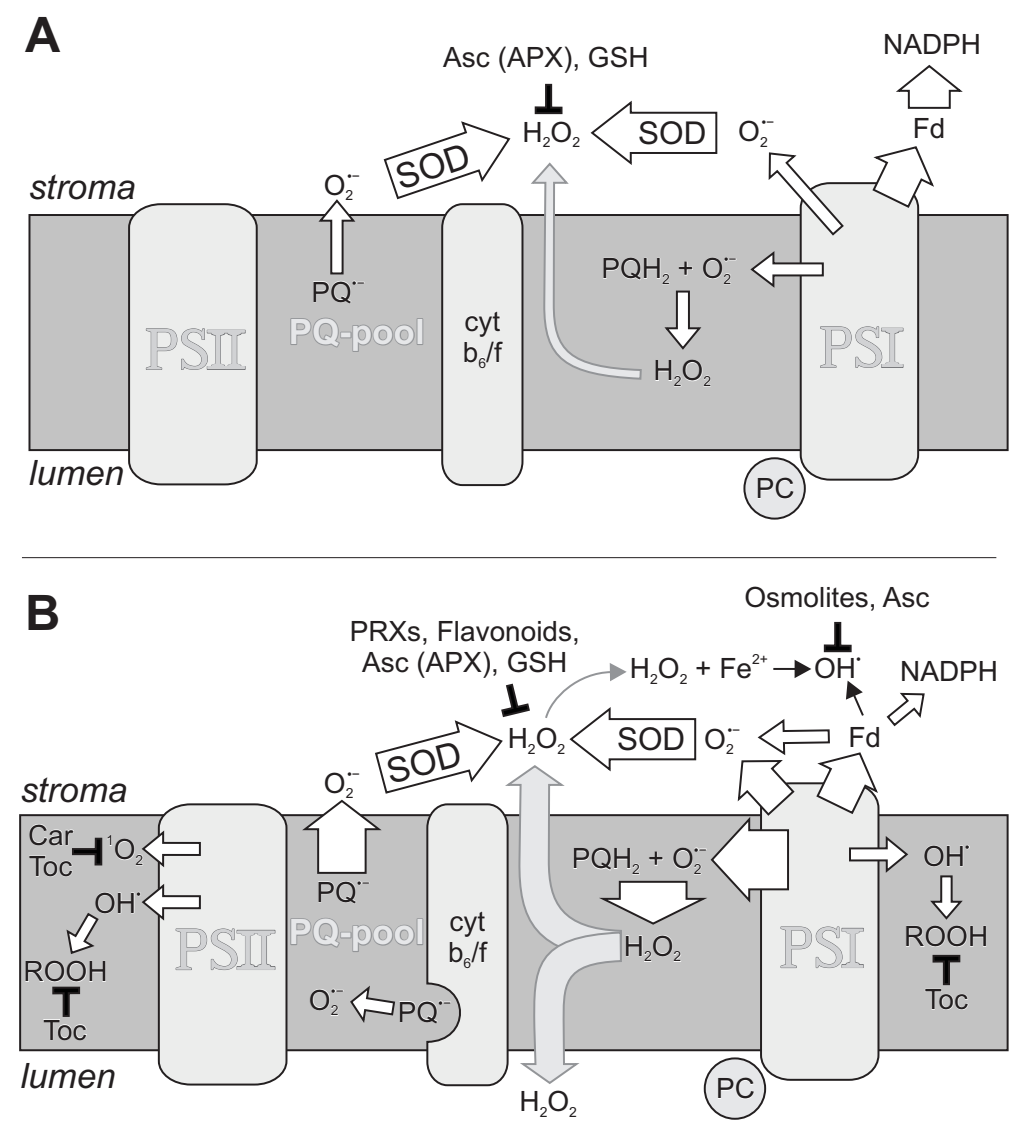

Fig. 1. The ways of ROS production and ROS scavenging in chloroplasts under normal functional conditions (A) and stress conditions (B). The scheme represents the putative ways of ROS production and scavenging that play the most important role in oxygen metabolism. APX, ascorbate peroxidase; Asc, ascorbate; Car, carotenoids; cyt $b_{6} / f$, cytochrome $b_{6} / f$ complex; Fd, ferredoxin; GSH, reduced glutathione; $\mathrm{PC}$, plastocyanin; $\mathrm{PQ}$, plastoquinone; $\mathrm{PQ}{ }^{*-}$, plastosemiquinone; $\mathrm{PQH}_{2}$, plastoquinol; PRXs, peroxiredoxins; PSI and PSII, photosystem I and II, respectively; SOD, superoxide dismutase; Toc, tocopherols. For details see text. 


\section{References}

Afanas'ev, I.B., Grabovetskii, V.V. \& Kuprianova, N.S. (1987). Kinetics and Mechanism of the Reactions of Superoxide Ion in Solution. Part 5. Kinetics and Mechanism of the Interaction of Superoxide Ion with Vitamin E and Ascorbic Acid. Journal of the Chemical Society, Perkin Transactions, 2, No. 3, (n.d.), pp. 281-285, ISSN 0300-9580

Afanas'ev, I.B. (1989). Superoxide Ion: Chemistry and Biological Implications, CRC Press, ISBN 978-084-9354-51-9, Boca Raton, Florida, USA

Agati, G., Matteini, P., Goti, A. \& Tattini, M. (2007). Chloroplast-Located Flavonoids Can Scavenge Singlet Oxygen. The New Phytologist, Vol. 174, No. 1, (April 2007), pp. 7789, ISSN 0028-646X

Alboresi, A., Dall'Osto, L., Aprile, A., Carillo, P., Roncaglia, E., Cattivelli, L. \& Bassi, R. (2011). Reactive Oxygen Species and Transcript Analysis upon Excess Light Treatment in Wild-Type Arabidopsis thaliana vs a Photosensitive Mutant Lacking Zeaxanthin and Lutein. BMC Plant Biology, Vol. 11:62 (April 2011) ISSN 1471-2229

Allen, J.F. \& Hall, D.O. (1973). Superoxide Reduction as a Mechanism of AscorbateStimulated Oxygen-Uptake by Isolated Chloroplasts. Biochemical and Biophysical Research Communications, Vol. 52, No. 3, (June 1973), pp. 856-862, ISSN 0006-291X

Allen, J.F. (1975). Oxygen Reduction and Optimum Production of ATP in Photosynthesis. Nature, Vol. 256, No. 5518, (August 1975), pp. 599-600, ISSN 0028-0836

Allen, J.F. (1975). A Two-Step Mechanism for Photosynthetic Reduction of Oxygen by Ferredoxin. Biochemical and Biophysical Research Communications, Vol. 66, No. 1, (September 1975), pp. 36-43, ISSN 0006-291X

Ananyev, G., Wydrzynski, T., Renger, G. \& Klimov, V. (1992). Transient Peroxide Formation by the Managense-Containing, Redox-Active Donor Side of Photosystem II upon Inhibition of $\mathrm{O}_{2}$ Evolution with Lauroylcholine Chloride. Biochimica et Biophysica Acta, Vol. 1100, No. 3, (June 1992), pp. 303-311, ISSN 0005-2728

Ananyev, G., Renger, G., Wacker U. \& Klimov V. (1994). The Photoproduction of Superoxide Radicals and the Superoxide Dismutase Activity of Photosystem II. The Possible Involvement of Cytochrome b559. Photosynthesis Research, Vol. 41, No. 2 , (August 1994), pp. 327-338, ISSN 0166-8595

Anderegg, G. \& Ripperger, H. (1989). Correlation between Metal Complex Formation and Biological Activity of Nicotianamine Analogues. Journal of the Chemical Society, Chemical Communications, Vol. 10, (n.d.), pp. 647-650, ISSN 0022-4936

Andersson, M.E. \& Nordlund, P. (1999). A Revised Model of the Active Site of Alternative Oxidase. FEBS Letters, Vol. 449, No. 1, (April 1999), pp. 17-22, ISSN 0014-5793

Anthony, J.R., Warczak, K.L. \& Donohue, T.J. (2005). A Ttranscriptional Response to Singlet Oxygen, a Toxic Byproduct of Photosynthesis. Proceedings of the National Academy of Sciences of the USA, Vol. 102, No. 18, (May 2005), pp. 6502-6507, ISSN 0027-8424

Apel, K. \& Hirt, H. (2004). Reactive Oxygen Species: Metabolism, Oxidative Stress, and Signal Transduction. Annual Review of Plant Biology, Vol. 55, (June 2004), pp. 373399, ISSN 1543-5008

Arato, A., Bondarava, N. \& Krieger-Liszkay, A. (2004). Production of Reactive Oxygen Species in Chloride- and Calcium-Depleted Photosystem II and their Involvement in Photoinhibition. Biochimica et Biophysica Acta, Vol. 1608, No. 2-3, (February 2004), pp. 171-180, ISSN 0005-2728 
Aro, E.M., Virgin, I. \& Andersson, B. (1993). Photoinhibition of Photosystem II. Inactivation, Protein Damage and Turnover. Biochimica et Biophysica Acta, Vol. 1143, No. 2, (July 1993), pp. 113-134, ISSN 0005-2728

Asada, K., Kiso, K. \& Yoshikawa K. (1974). Univalent Reduction of Molecular Oxygen by Spinach Chloroplasts on Illumination. The Journal of Biological Chemistry, Vol. 249, No. 7, (April 1974), pp. 2175-2181, ISSN 0021-9258

Asada, K. \& Takahashi, M. (1987). Production and Scavenging of Active Oxygen in Photosynthesis, In: Photoinhibition, D.J. Kyle, C.B. Osmond \& C.J. Arntzen, (Eds), pp. 227-287, Elsevier, ISBN 978-044-4415-96-7, Amsterdam, The Netherlands

Asada, K. (1994). Production and Action of Active Oxygen Species in Photosynthesis Tissues, In: Causes of Photooxidative Stress and Amelioration of Defense Systems in Plants, C.H. Foyer \& P.M. Mullineaux, (Eds), pp. 78-104, CRC Press, ISBN 978-0849354-43-4, Boca Raton, Florida, USA

Asada, K. (1999). The Water-Water Cycle in Chloroplasts: Scavenging of Active Oxygens and Dissipation of Excess Photons. Annual Review of Plant Physiology $\mathcal{E}$ Plant Molecular Biology, Vol. 50, (June 1999), pp. 601-639, ISSN 1040-2519

Babu, T.S., Akhtar, T.A., Lampi, M.A., Tripuranthakam, S., Dixon, R. \& Greenber, B.M. (2003). Similar Stress Responses Are Elicited by Copper and Ultraviolet Radiation in the Aquatic Plant Lemma gibba: Implication of Reactive Oxygen Species as Common Signals. Plant \& Cell Physiology, Vol. 44, No. 12, (December 2003), pp. 1320-1329, ISSN 0032-0781

Backhausen, J.E., Kitzmann, C., Horton, P. \& Scheibe, R. (2000). Electron Acceptors in Isolated Intact Spinach Chloroplasts Act Hierarchically to Prevent Over-Reduction and Competition for Electrons. Photosynthesis Research, Vol. 64, No. 1, (April 2000), pp. 1-13, ISSN 0166-8595

Badger, M.R. (1985). Photosynthetic Oxygen Exchange. Annual Review of Plant Physiology, Vol. 36, (June 1985), pp. 27-53, ISSN 0066-4294

Badger, M.R., von Caemmerer, S., Ruuska, S. \& Nakano, H. (2000). Electron Flow to Oxygen in Higher Plants and Algae: Rates and Control of Direct Photoreduction (Mehler Reaction) and Rubisco Oxygenase. Philosophical Transactions of the Royal Society of London. Series B, Biological Sciences, Vol. 355, No. 1402, (October 2000), pp. 1433 1446, ISSN 0962-8436

Baier, M. \& Dietz, K.J. (2005). Chloroplasts as Source and Target of Cellular Redox Regulation: a Discussion on Chloroplast Redox Signals in the Context of Plant Physiology. Journal of Experimental Botany, Vol. 56, No. 416, (June 2005), pp. 14491462, ISSN 0022-0957

Barber, J. (2008). Crystal Structure of the Oxygen-Evolving Complex of Photosystem II. Inorganic Chemistry, Vol. 47, No. 6, (March 2008), pp. 1700-1710, ISSN 0020-1669

Baruah, A., Simkova, K., Apel, K. \& Laloi, C. (2009). Arabidopsis Mutants Reveal Multiple Singlet Oxygen Signaling Pathways Involved in Stress Response and Development. Plant Molecular Biology, Vol. 70, No. 5, (July 2009), pp. 547-563, ISSN 0167-4412

Bechtold, U., Richard, O., Zamboni, A., Gapper, C., Geisler, M., Pogson, B., Karpinski, S. \& Mullineaux, P. (2008). Impact of Chloroplastic- and Extracellular-Sourced ROS on High Light-Responsive Gene Expression in Arabidopsis. Journal of Experimental Botany, Vol. 59, No. 2, (January 2008), pp. 121-133, ISSN 0022-0957 
Beck, C.F. (2005). Signaling Pathways from the Chloroplast to the Nucleus. Planta, Vol. 222, No. 5, (November 2005), pp. 743-756, ISSN 0032-0935

Bielski, B.H.J., Arudi, R.L. \& Sutherland, M.W. (1983). A Study of the Reactivity of $\mathrm{HO}_{2} / \mathrm{O}_{2}{ }^{-}-$ with Unsaturated Fatty Acids. The Journal of Biological Chemistry, Vol. 258, No. 8, (April 1983), pp. 4759-4761, ISSN 0021-9258

Bolouri-Moghaddam, M.R., Le Roy, K., Xiang, L., Rolland, F. \& van den Ende, W. (2010). Sugar Signalling and Antioxidant Network Connections in Plant Cells. FEBS Journal, Vol. 277, No. 9, (May 2010), pp. 2022-2037, ISSN 1742-464X

Bondarava, N., Gross, C.M., Mubarakshina, M.M., Golecki, J.R., Johnson, G.N. \& KriegerLiszkay, A. (2010). Putative Function of Cytochrome b559 as a Plastoquinol Oxidase. Physiologia Plantarum, Vol. 138, No. 4, (April 2010), pp. 463-473., ISSN 0031-9317

Brettel, K. \& Leibl, W. (2001). Electron Transfer in Photosystem I. Biochimica et Biophysica Acta, Vol. 1507, No. 1-3, (October 2001), pp. 100-114, ISSN 0005-2728

Broin, M., Cuiné, S., Eymery, F. \& Rey, P. (2002). The Plastidic 2-Cysteine Peroxiredoxin Is a Target for a Thioredoxin Involved in the Protection of the Photosynthetic Apparatus against Oxidative Damage. The Plant Cell, Vol. 14, No. 6, (June 2002), pp. 1417-1432, ISSN 1040-4651

Brudvig, G.W. (2008). Water Oxidation Chemistry of Photosystem II. Philosophical Transactions of the Royal Society of London. Series B, Biological Sciences, Vol. 363, No. 1494, (March 2008), pp. 1211-1218, ISSN 0962-8436

Byczkowsky, J.Z. \& Gessener, T. (1988). Biological Role of Superoxide Ion-Radical. The International Journal of Biochemistry, Vol. 20, No. 6, (February 1988), pp. 569-580, ISSN 0020-711X

Cadet, J., Delatour, T., Douki, T., Gasparutto, D., Pouget, J., Ravanat, J. \& Sauvaigo, S. (1999). Hydroxyl Radicals and DNA Base Damage. Mutation Research, Vol. 424, No. 1-2, (March 1999), pp. 9-21, ISSN 0027-5107

Camacho-Pereira, J., Meyer, L.E., Machado, L.B., Oliveira, M.F. \& Galina, A. (2009). Reactive Oxygen Species Production by Potato Tuber Mitochondria is Modulated by Mitochondrially Bound Hexokinase Activity. Plant Physiology, Vol. 149, No. 2, (February 2009), pp. 1099-1110, ISSN 0032-0889

Chan, K.X., Crisp, P.A., Estavillo, G.M. \& Pogson, B.J. (2010). Chloroplast-to-Nucleus Communication: Current Knowledge, Experimental Strategies and Relationship to Drought Stress Signaling. Plant Signaling \& Behavior, Vol. 5, No. 12, (December 2010), pp. 1575-1582, ISSN 1559-2316

Charles, S.A. \& Halliwell, B. (1980). Effect of Hydrogen Peroxide on Spinach (Spinacia oleracea) Chloroplast Fructose Bisphosphatase. The Biochemical Journal, Vol. 189, No. 2, (August 1980), pp. 373-376, ISSN 0264-6021

Cogdell, R.J., Howard, T.D., Bittl, R., Schlodder, E., Geisenheimer, I. \& Lubitz, W. (2000). How Carotenoids Protect Bacterial Photosynthesis. Philosophical Transactions of the Royal Society of London. Series B, Biological Sciences, Vol. 355, No. 1402, (October 2000), pp. 1345-1349, ISSN 0962-8436

Coupe, S.A., Palmer, B.G. \& Lake, J.A. (2006). Systemic Signaling of Environmental Cues in Arabidopsis Leaves. Journal of Experimental Botany, Vol. 57, No. 2, (January 2006) pp. 329-341, ISSN 0022-0957 
Cui, L., Veeraraghavan, N., Richter, A., Wall, K., Jansen, R.K., Leebens-Mack, J., Makalowska, I. \& de Pamphilis, C.W. (2006). ChloroplastDB: the Chloroplast Genome Database. Nucleic Acids Research, Vol. 34, (January 2006), pp. D692-696, ISSN 0305-1048

Dalton, D.A., Russell, S.A., Hanus, F.J., Pascoe, G.A. \& Evans, H.J. (1986). Enzymatic Reactions of Ascorbate and Glutathione That Prevent Peroxide Damage in Soybean Root Nodules. Proceedings of the National Academy of Sciences of the USA, Vol. 83, No. 11, (June 1986), pp. 3811-3815, ISSN 0027-8424

Danna, C.H., Bartoli, C.G., Sacco, F., Ingala, L.R., Santa-Maria, G.E., Guiamet, J.J. \& Ugalde, R.A. (2003). Thylakoid-Bound Ascorbate Peroxidase Mutant Exhibits Impaired Electron Transport and Photosynthetic Activity. Plant Physiology, Vol. 132, No. 4, (August 2003), pp. 2116-2125, ISSN 0032-0889

Dat, J., Vandenabeele, S., Vranova, E., van Montagu, M., Inze, D. \& van Breusegem, F. (2000). Dual Action of the Active Oxygen Species During Plant Stress Responses. Cellular \& Molecular Life Sciences, Vol. 57, No. 5, (May 2000), pp. 779-795, ISSN 1420$682 X$

Dekker, J.P. \& van Grondelle, R. (2000). Primary Charge Separation in Photosystem II. Photosynthesis research, Vol. 63, No. 3, (March 2000), pp. 195-208, ISSN 0166-8595

Demmig-Adams, B. (1990). Carotenoids and Photoprotection in Plants: A Role for the Xanthophyll Zeaxanthin. Biochimica et Biophysica Acta, Vol. 1020, No. 1, (October 1990), pp. 1-24, ISSN 0005-2728

Desikan, R., Clarke, A., Hancock, J.T. \& Neill, S.J. (1999). $\mathrm{H}_{2} \mathrm{O}_{2}$ Activates a MAP Kinase-Like Enzyme in Arabidopsis thaliana Suspension Cultures. Journal of Experimental Botany, Vol. 50, No. 341, (December 1999), pp. 1863-1866, ISSN 0022-0957

Desikan, R., Mackerness, S., Hancock, J.T. \& Neill, S.J. (2001). Regulation of the Arabidopsis Transcriptome by Oxidative Stress. Plant Physiology, Vol. 127, No. 1, (September 2001), pp. 159-172, ISSN 0032-0889

Devasagayam, T.P., Sundquist, A.R., Di Mascio, P., Kaiser, S. \& Sies, H. (1991). Activity of Thiols as Singlet Molecular Oxygen Quenchers. Journal of Photochemistry and Photobiology. B, Biology, Vol. 9, No. 1, (April 1991), pp. 105-116, ISSN 1011-1344

Dietz, K.J., Jacob, S., Oelze, M.L., Laxa, M., Tognetti, V., de Miranda, S.M.N., Baier, M. \& Finkemeier, I. (2006). The Function of Peroxiredoxins in Plant Organelle Redox Metabolism. Journal of Experimental Botany, Vol. 57, No. 8, (May 2006), pp. 16971709, ISSN 0022-0957

Ding, M.Q., Hou, P.C., Shen, X., Wang, M.J., Deng, S.R., Sun, J., Xiao, F., Wang, R., Zhou, X., Lu, C., Zhang, D., Zheng, X., Hu, Z. \& Chen, S. (2010). Salt-Induced Expression of Genes Related to $\mathrm{Na}+\mathrm{K}+$ and ROS Homeostasis in Leaves of Salt-Resistant and Salt-Sensitive Poplar Species. Plant Molecular Biology, Vol. 73, No. 3, (June 2010), pp. 251-269, ISSN 0167-4412

Dron, M., Clouse, S.D., Dixon, R.A., Lawton, M.A. \& Lamb, C.J. (1988). Glutathione and Fungal Elicitor Regulation of a Plant Defense Gene Promoter in Electroporated Protoplasts. Proceedings of the National Academy of Sciences of the USA, Vol. 85, No. 18, (September 1988), pp. 6738-6742, ISSN 0027-8424

Eisenhut, M., Ruth, W., Haimovich, M., Bauwe, H., Kaplan, A. \& Hagemann, M. (2008). The Photorespiratory Glycolate Metabolism Is Essential for Cyanobacteria and Might Have Been Conveyed Endosymbiontically to Plants. Proceedings of the National 
Academy of Sciences of the USA, Vol. 105, No. 44, (November 2008), pp. 17199-17204, ISSN 0027-8424

Escoubas, J.M., Lomas, M., LaRoche, J. \& Falkowski P.G. (1995). Light Intensity Regulation of cab Gene Transcription is Signaled by the Redox State of the Plastoquinone Pool. Proceedings of the National Academy of Sciences of the USA, Vol. 92, No. 22, (October 1995), pp. 10237-10241, ISSN 0027-8424

Eshdat, Y., Holland, D., Faltin, Z. \& Ben-Hayyim, G. (1997). Plant Glutathione Peroxidases. Physiologia Plantarum, Vol. 100, No. 2, (June 1997), pp. 234-240, ISSN 0031-9317

Fahnenstich, H., Scarpeci, T.E., Valle, E.M., Fliigge, U.I. \& Maurino, V.G. (2008). Generation of Hydrogen Peroxide in Chloroplasts of Arabidopsis Overexpressing Glycolate Oxidase as an Inducible System to Study Oxidative Stress. Plant Physiology, Vol. 148, No. 2, (October 2008), pp. 719- 729, ISSN 0032-0889

Fey, V., Wagner, R., Brautigam, K., Wirtz, M., Hell, R., Dietzmann, A., Leister, D., Oelmüller, R. \& Pfannschmidt, T. (2005). Retrograde Plastid Redox Signals in the Expression of Nuclear Genes for Chloroplast Proteins of Arabidopsis thaliana. The Journal of biological chemistry, Vol. 280, No. 7, (February 2005), pp. 5318-5328, ISSN 0021-9258

Filella, I., Peñuelas, J. \& Llusià, J. (2006). Dynamics of the Enhanced Emissions of Monoterpenes and Methyl Salicylate, and Decreased Uptake of Formaldehyde, by Quercus ilex Leaves after Application of Jasmonic Acid. The New phytologist, Vol. 169, No. 1, (January 2006), pp.135-144, ISSN 0028-646X

Foote, C.S. \& Denny, R.W. (1968). Chemistry of Singlet Oxygen. VII. Quenching by $\beta-$ Carotene. Journal of the American Chemical Society, Vol. 90, No. 22, (October 1968), pp. 6233-6235, ISSN 0002-7863

Foyer CH, \& Noctor G. (2009) Redox Regulation in Photosynthetic Organisms: Signaling, Acclimation, and Practical Implications. Antioxidants \& Redox Signaling, Vol. 11, No. 4, (April 2009), pp. 861-905, ISSN 1523-0864

Frigerio, S., Campoli, C., Zorzan, S., Fantoni, L.I., Crosatti, C., Drepper, F., Haehnel, W., Cattivelli, L., Morosinotto, T. \& Bassi, R. (2007). Photosynthetic Antenna Size in Higher Plants Is Controlled by the Plastoquinone Redox State at the Posttranscriptional Rather than Transcriptional Level. The Journal of Biological Chemistry, Vol. 282, No. 40, (October 2007), pp. 29457-29469, ISSN 0021-9258

Fujiwara, K., Kumata, H., Kando, N., Sakuma, E., Aihara, M., Morita, Y. \& Miyakawa, T. (2006). Flow Injection Analysis to Measure the Production Ability of Superoxide with Chemiluminescence Detection in Natural Waters. International Journal of Environmental Analytical Chemistry, Vol. 86, No. 5, (April 2006), pp. 337-346, ISSN 0306-7319

Furbank, R. \& Badger, M. (1983). Oxygen Exchange Associated with Electron Transport and Photophosphorilation in Spinach Thylakoids. Biochimica et Biophysica Acta, Vol. 723, No. 3, (June 1983), pp. 400-409, ISSN 0005-2728

Gadjev, I., Vanderauwera, S., Gechev, T.S., Laloi, C., Minkov, I.N., Shulaev, V., Apel, K., Inze, D., Mittler, R. \& van Breusegem, F. (2006). Transcriptomic Footprints Disclose Specificity of Reactive Oxygen Species Signaling in Arabidopsis. Plant Physiology, Vol. 141, No. 2, (June 2006), pp. 436-445, ISSN 0032-0889

Geigenberger, P., Kolbe, A. \& Tiessn, A. (2005). Redox Regulation of Carbon Storage and Partitioning in Response to Light and Sugars. Journal of Experimental Botany, Vol. 56, No. 416, (June 2006), pp. 1469-1479, ISSN 0022-0957 
Golbeck, J. \& Radmer, R. (1984). Is the Rate of Oxygen Uptake by Reduced Ferredoxin Sufficient to Account for Photosystem I - Mediated $\mathrm{O}_{2}$ Reduction?, In: Advances in Photosynthesis Research, C. Sybesma (Ed), pp. 1.4.561 - 1.4.564, Martinus Nijhoff/Dr W. Junk, ISBN 978-902-4729-42-5, Hague, The Netherlands

Gotoh, N. \& Niki E. (1992). Rates of Interactions of Superoxide with Vitamin E, Vitamin C and Related Compounds as Measured by Chemiluminescence. Biochimica et Biophysica Acta, Vol. 1115, No. 3, (January 1992), pp. 201-207, ISSN 0005-2728

Grant, J.J., Yun, B.W. \& Loake, G.J. (2000). Oxidative Burst and Cognate Redox Signalling Reported by Luciferase Imaging: Identification of a Signal Network that Functions Independently of Ethylene, SA and Me-JA but Is Dependent on MAPKK Activity. The Plant Journal, Vol. 24, No. 5, (December 2000), pp. 569-582, ISSN 0960-7412

Gray, J.C. (2003). Chloroplast-to-Nucleus Signalling: a Role for Mg-Protoporphyrin. Trends in Genetics, Vol. 19, No. 10, (October 2003), pp. 526-529, ISSN 0168-9525

Gruszka, J., Pawlak, A. \& Kruk, J. (2008). Tocochromanols, Plastoquinol, and Other biological Prenyllipids as Singlet Oxygen Quenchers-Determination of Singlet Oxygen Quenching Rate Constants and Oxidation Products. Free Radical Biology $\mathcal{E}$ Medicine, Vol. 45, No. 6, (September 2008), pp. 920-928, ISSN 0891-5849

Gupta, A.K. \& Kaur, N. (2005). Sugar Signalling and Gene Expression in Relation to Carbohydrate Metabolism under Abiotic Stresses in Plants. Journal of Biosciences, Vol. 30, No. 5, (December 2005), pp. 761-776, ISSN 0250-5991

Gus'kova, R.A., Ivanov, I.I., Kol'tover, V.K., Akhobadze, V.V. \& Rubin, A.B. (1984). Permeability of Bilayer Lipid Membranes for Superoxide $\left(\mathrm{O}_{2}{ }^{--}\right)$Radicals. Biochimica et Biophysica Acta, Vol. 778, No. 3, (December 1984), pp. 579-585, ISSN 0005-2728

Hatz, S., Lambert, J.D.C. \& Ogilby, P.R. (2007). Measuring the Lifetime of Singlet Oxygen in a Single Cell: Addressing the Issue of Cell Viability. Photochemical \& Photobiological Sciences, Vol. 6, No. 10, (October 2007), pp. 1106-1116, ISSN 1474-905X

Havaux, M., Eymery, F., Porfirova, S., Rey, P. \& Dörmann, P. (2005). Vitamin E Protects against Photoinhibition and Photooxidative Stress in Arabidopsis thaliana. The Plant Cell, Vol. 17, No. 12, (December 2005), pp. 3451-69, ISSN 1040-4651

Heber, U. (1973). Stoichiometry of Reduction and Phosphorylation during Illumination of Intact Chloroplasts. Biochimica et Biophysica Acta, Vol. 305, No. 1, (April 1973), pp. 140-152, ISSN 0005-2728

Hernández, I., Alegre, L., van Breusegem, F. \& Munné-Bosch, S. (2009). How Relevant are Flavonoids as Antioxidants in Plants? Trends in Plant Science, Vol. 14, No.3, (March 2009), pp. 125-132, ISSN 1360-1385

Heyno, E., Gross, C.M., Laureau, C., Culcasi, M., Pietri, S. \& Krieger-Liszkay, A. (2009). Plastid Alternative Oxidase (PTOX) Promotes Oxidative Stress When Overexpressed in Tobacco. The Journal of Biological Chemistry, Vol. 284, No. 45, (November 2009), pp. 31174-31180, ISSN 0021-9258

Hideg, E.E., Ogawa, K., Kalai, T. \& Hideg, K. (2001). Singlet Oxygen Imaging in Arabidopsis thaliana Leaves under Photoinhibition by Excess Photosynthetically Active Radiation. Physiologia Plantarum, Vol. 112, No. 1, (May 2001), pp. 10-14, ISSN 00319317

Hillier, W. \& Wydrzynski, T. (1993). Increases in Peroxide Formation by the $\mathrm{O}_{2}$-Evolving Catalytic Site Upon the Removal of the Extrinsic 16-, 23-, and 33-kDa Proteins Are 
Reversed by $\mathrm{CaCl}_{2}$ Addition. Photosynthesis Research, Vol. 38, No. 3, (January 1993), pp. 417-423, ISSN 0166-8595

Horton, P., Ruban, A.V. \& Walters, R.G. (1996) Regulation of Light Harvesting in Green Plants. Annual Review of Plant Physiology \& Plant Molecular Biology, Vol. 47, (June 1996), pp. 655-684, ISSN 1040-2519

Hosein, B. \& Palmer, G. (1983). The Kinetics and Mechanism of Oxidation of Reduced Spinach Ferredoxin by Molecular Oxygen and its Reduced Products. Biochimica et Biophysica Acta, Vol. 723, No. 3, (June 1983), pp. 383-390, ISSN 0005-2728

Hundal, T., Forsmark-Andrée, P., Ernster, L. \& Andersson, B. (1995). Antioxidant Activity of Reduced Plastoquinone in Chloroplast Thylakoid Membranes. Archives of Biochemistry and Biophysics, Vol. 324, No. 1, (December 1995), pp. 117-122, ISSN 0003-9861

Ivanov, B.N., Red'ko, T.P., Shmeleva, V.L. \& Mukhin, E.N. (1980). The Role of Ferredoxin in Pseudocyclic Electron Transport in Isolated Pea Chloroplasts. Biochemistry (Moscow), Vol. 45, No. 8, (August 1980), pp. 1425-1432, ISSN 0320-9725

Ivanov, B.N. (1993). Stoichiometry of Proton Uptake by Thylakoids during Electron Transport in Chloroplasts. In: Photosynthesis. Photoreactions to Plant Productivity, Y. P. Abrol, P. Mohanty \& Govindjee (Eds.), pp. 109-132, Kluwer Academic Publishers, ISBN 978-079-2319-43-6, New Delhi: Oxford

Ivanov, B.N., Kobayashi, Y., Bukhov, N.K. \& Heber, U. (1998). Photosystem I-Dependent Cyclic ElectronF in Intact Spinach Chloroplasts: Occurrence, Dependence on Redox Conditions and Electron Acceptors and Inhibition by Antimycin A. Photosynthesis Research, Vol. 57, No., (), pp. 61-70, ISSN 0166-8595

Ivanov, B. \& Edwards, G. (2000). Influence of Ascorbate and the Mehler Peroxidase Reaction on Non-Photochemical Quenching of Chlorophyll Fluorescence in Maize Mesophyll Chloroplasts. Planta, Vol. 210, No. 5, (April 2000), pp. 765-774, ISSN 0032-0935

Ivanov, B.N., Mubarakshina, M.M. \& Khorobrykh, S.A. (2007). Kinetics of the Plastoquinone Pool Oxidation Following Illumination. Oxygen Incorporation into Photosynthetic Electron Transport Chain. FEBS Letters, Vol. 581, No. 7, (April 2007), pp. 1342-1346., ISSN 0014-5793

Kaiser, W. (1976). The Effect of Hydrogen Peroxide on $\mathrm{CO}_{2}$-Fixation of Isolated Chloroplasts. Biochimica et Biophysica Acta, Vol. 440, No. 3, (September 1976), pp. 476-482, ISSN 0005-2728

Kaiser, W. (1979). Reversible Inhibition of the Calvin Cycle and Activation of Oxidative Pentose Phosphate Cycle in Isolated Intact Chloroplasts by Hydrogen Peroxide. Planta, Vol. 145, No. 4, (January 1979), pp. 377-382, ISSN 0032-0935

Kangasjärvi, S., Lepistö, A., Hännikäinen, K., Piippo, M., Luomala, E.M., Aro, E.M. \& Rintamäki, E. (2008). Diverse Roles for Chloroplast Stromal and Thylakoid-Bound Ascorbate Peroxidases in Plant Stress Responses. Biochemical Journal, Vol. 412, No. 2, (June 2008), pp 275-285, ISSN 0264-6021

Keren, N., Gong, H. \& Ohad, I. (1995). Oscillations of Reaction Centre II D1 Protein Degradation in vivo Induced by Repetitive Flashes. The Journal of Biological Chemistry, Vol. 270, No. 2, (January 1995), pp. 806-814, ISSN 0021-9258 
Khorobrykh, S.A. \& Ivanov, B.N. (2002). Oxygen Reduction in a Plastoquinone Pool of Isolated Pea Thylakoids. Photosynthesis Research, Vol. 71, No. 3, (March 2002), pp. 209-219, ISSN 0166-8595

Khorobrykh, S.A., Khorobrykh, A.A., Klimov, V.V. \& Ivanov, BN. (2002). Photoconsumption of Oxygen in Photosystem II Preparations under Impairment of Water-Oxidation Complex. Biochemistry (Moscow), Vol. 67, No. 6, (June 2002), pp. 683-688, ISSN 00062979

Khorobrykh, S., Mubarakshina, M. \& Ivanov, B. (2004). Photosystem I is not Solely Responsible for Oxygen Reduction in Isolated Thylakoids. Biochimica et Biophysica Acta, Vol. 1657, No. 2-3, (July 2004), pp. 164-167, ISSN 0005-2728

Khorobrykh, S.A., Khorobrykh, A.A., Yanykin, D.V., Ivanov, B.N., Klimov, B.N. \& Mano, J., submitted. Photoproduction of Catalase-Insensitive Peroxides on the Donor Side of Manganese-Depleted Photosystem II: Evidence with a Specific Fluorescent Probe. Biochemistry (accepted)

Klimov, V.V., Ananyev, G.M., Zastrizhnaya, O.M., Wydrzynski, T. \& Renger, G. (1993). Photoproduction of Hydrogen Peroxide in Photosystem II Membrane Fragments. A Comparison of Four Signals. Photosynthesis Research, Vol. 38, No. 3, (January 1993), pp. 409-416, ISSN 0166-8595

Kozuleva, M.A., Naidov, I.A., Mubarakshina, M.M. \& Ivanov, B.N. (2007). Participation of Ferredoxin in Oxygen Reduction by the Photosynthetic Electron Transport Chain. Biofizika, Vol. 52, No. 4, (July-August 2007), pp. 650-655, ISSN 0006-3029

Kozuleva, M.A. \& Ivanov, B.N. (2010). Evaluation of the Participation of Ferredoxin in Oxygen Reduction in the Photosynthetic Electron Transport Chain of Isolated Pea Thylakoids. Photosynthesis Research, Vol. 105, No. 1, (July 2010), pp. 51-61, ISSN 0166-8595

Kozuleva, M., Klenina, I., Proskuryakov, I., Kirilyuk, I. \& Ivanov, B. (2011). Production of Superoxide in Chloroplast Thylakoid Membranes. ESR Study with Cyclic Hydroxylamines of Different Lipophilicity. FEBS Letters, Vol. 585, No. 7, (April 2011), pp. 1067-1071, ISSN 0014-5793

Krasnovsky, A.A., Jr. (1998). Singlet Molecular Oxygen in Photobiochemical Systems: IR Phosphorescence Studies. Membrane \& Cell Biology, Vol. 12, No. 5, (n.d.), pp. 665690, ISSN 1023-6597

Krieger, A., Rutherford, A.W. \& Johnson, G.N. (1995). On the Determination of Redox Midpoint Potential of the Primary Quinone Electron Acceptor, $\mathrm{Q}_{\mathrm{A}}$, in Photosystem II. Biochimica et Biophysica Acta, Vol. 1229, No. 2, (April 1995), pp. 193-201, ISSN 0005-2728

Krieger-Liszkay, A. \& Rutherford, A.W. (1998). Influence of Herbicide Binding on the Redox Potential of the Quinone Acceptor in Photosystem II: Relevance to Photodamage and Phytotoxicity. Biochemistry, Vol. 37, No. 50, (December 1998), pp. 17339-17344, ISSN 0006-2960

Krieger-Liszkay, A. (2005). Singlet Oxygen Production in Photosynthesis. Journal of Experimental Botany, Vol. 56, No. 411, (January 2005), pp. 337-346, ISSN 0022-0957

Krieger-Liszkay, A., Kós, P.B., Hideg, E. (2011). Superoxide Anion Radicals Generated by Methylviologen in Photosystem I Damage Photosystem II. Physiologia Plantarum, Vol. 142, No. 1, (May 2011), pp. 17-25, 0031-9317 
Kropat, J., Oster, U., Rüdiger, W. \& Beck, C.F. (1997). Chlorophyll Precursors are Signals of Chloroplast Origin Involved in Light Induction of Nuclear Heat Shock Genes. Proceedings of the National Academy of Sciences of the USA, Vol. 94, No. 25, (December 1997), pp. 14168 - 14172, ISSN 0027-8424

Kruk, J., Schmid, G.H. \& Strzałka, K. (1994). Antioxidant Properties of Plastoquinol and Other Biological Prenylquinols in Liposomes and Solution. Free Radical Research, Vol. 21, No. 6, (November-December 1994), pp. 409-416, ISSN 1029-2470

Kruk, J., Jemioła-Rzemińska, M. \& Strzałka, K. (1997). Plastoquinol and a-Tocopherol Quinol Are More Active than Ubiquinol and a-Tocopherol in Inhibition of Lipid Peroxidation. Chemistry and Physics of Lipids, Vol. 87, No. 1, (May 1997), pp. 73-80, ISSN 0009-3084

Kruk, J., Jemiola-Rzeminska, M., Burda, K., Schmid, G. \& Strzalka, K. (2003). Scavenging of Superoxide Generated in Photosystem I by Plastoquinol and Other Prenyllipids in Thylakoid Membranes. Biochemistry, Vol. 42, No. 1, (October 2003), pp. 8501-8505, ISSN 0264-6021

Kruk, J. \& Trebst, A. (2008). Plastoquinol as a Singlet Oxygen Scavenger in Photosystem II. Biochimica et Biophysica Acta, Vol. 1777, No. 2, (February 2008), pp. 154-162, ISSN 0005-2728

Kurepa, J., Hérouart, D., van Montagu, M. \& Inzé D. (1997). Differential Expression of CuZn-and Fe-Superoxide Dismutase Genes of Tobacco during Development, Oxidative Stress, and Hormonal Treatments. Plant E Cell Physiology, Vol. 38, No. 4, (April 1997), pp. 463-470, ISSN 0032-0781

Kuvykin, I.V., Vershubskii, A.V., Ptushenko, V.V. \& Tikhonov, A.N. (2008). Oxygen as an Alternative Electron Acceptor in the Photosynthetic Electron Transport Chain of C3 Plants. Biochemistry (Moscow), Vol.73, No. 10, (October 2008), pp. 1063-1075, ISSN 0006-2979

Laloi, C., Przybyla, D. \& Apel, K. (2006). A Genetic Approach Towards Elucidating the Biological Activity of Different Reactive Oxygen Species in Arabidopsis thaliana. Journal of Experimental Botany, Vol. 57, No. 8, (May 2006), pp. 1719-1724, ISSN 00220957

Ledford, H.K., Chin, B.L. \& Niyogi, K.K. (2007). Acclimation to Singlet Oxygen Stress in Chlamydomonas reinhardtii. Eukaryotic Cell, Vol. 6, No. 6, (June 2007), pp. 919-930, ISSN 1535-9786

Lemaire, D.S., Michelet, L., Zaffagnini, M., Massot, V. \& Issakidis-Bourguet, E. (2007). Thioredoxins in Chloroplasts. Current Genetics, Vol. 51, No. 6, (June 2007), pp. 343365, ISSN 0172-8083

Lennon, A.M., Prommeenate, P. \& Nixon, P.J. (2003). Location, Expression and Orientation of the Putative Chlororespiratory Enzymes, Ndh and IMMUTANS, in Higher-Plant Plastids. Planta, Vol. 218, No. 2, (December 2003), pp. 254-260, ISSN 0032-0935

Li, Z., Wakao, S., Fischer, B.B. \& Niyogi, K.K. (2009). Sensing and Responding to Excess Light. Annual Review of Plant Biology, Vol. 60, (June 2009), pp. 239-260, 1543-5008

Lichtenthaler, H.K. (2007). Biosynthesis, Accumulation and Emission of Carotenoids, aTocopherol, Plastoquinone, and Isoprene in Leaves under High Photosynthetic Irradiance. Photosynthesis Research, Vol. 92, No. 2, (May 2007), pp. 163-179, ISSN 0166-8595 
Ligeza, A., Tikhonov, A.N., Hyde, J.S. \& Subczynski, W.K. (1998). Oxygen Permeability of Thylakoid Membranes: Electron Paramagnetic Resonance Spin Labeling Study. Biochimica et Biophysica Acta, Vol. 1365, No. 3, (July 1998), pp. 453-463, ISSN 00052728

Lindahl, M. \& Kieselbach, T. (2009). Disulphide Proteomes and Interactions with Thioredoxin on the Track Towards Understanding Redox Regulation in Chloroplasts and Cyanobacteria. Journal of Proteomics, Vol. 72, No. 3, (April 2009), pp. 416-438, ISSN 1876-7737

Maciejewska, U., Polkowska-Kowalczyk, L., Swiezewska, E. \& Szkopinska, A. (2002). Plastoquinone: Possible Involvement in Plant Disease Resistance. Acta Biochimica Polonica, Vol. 49, No. 3, (n.d.), pp. 775-780, ISSN 0001-527X

Maeda, H. \& DellaPenna, D. (2007). Tocopherol functions in photosynthetic organisms. Current Opinion in Plant Biology, Vol. 10, No.3, (June 2007), pp. 260-265, ISSN 13695266

Mateo, A., Funck, D., Mühlenbock, P., Kular, B., Mullineaux, P.M. \& Karpinski, S. (2006). Controlled Levels of Salicylic Acid Are Required for Optimal Photosynthesis and Redox Homeostasis. Journal of Experimental Botany, Vol. 57, No. 8, (May 2006), pp. 1795-1807, ISSN 0022-0957

Matheson, I.B.C., Etheridge, R.D., Kratowich, N.R. \& Lee, J. (1975). The Quenching of Singlet Oxygen by Amino Acids and Proteins. Photochemistry \& Photobiology, Vol. 21, No. 3, (March 1975), pp. 165-171, ISSN 0031-8655

Matysik, J., Alia, Bhalu, B. \& Mohanty, P. (2002). Molecular Mechanisms of Quenching of Reactive Oxygen Species by Proline under Stress in Plants. Current Science, Vol. 82, No. 5, (March 2002), pp.525-532, ISSN 0011-3891

Maurino, V.G.,\& Peterhansel, C. (2010). Photorespiration: Current Status and Approaches for Metabolic Engineering. Current Opinion in Plant Biology, Vol. 13, No. 3, (June 2010), pp. 249-256, ISSN 1369-5266

Mehler, A.C. (1951). Studies on Reactions of Illuminated Chloroplasts. I. Mechanism of the Reduction of Oxygen and Other Hill Reagents. Archives of Biochemistry and Biophysics, Vol. 33, No. 1, (August 1951), pp. 65-77, ISSN 0003-9861

Mittler, R., Vanderauwera, S., Gollery, M. \& Van Breusegem, F. (2004). The Reactive Oxygen Gene Network in Plants. Trends in Plant Science, Vol. 9, No. 10, (October 2004), pp. 490-498, ISSN 1360-1385

Miyake, C. \& Asada, K. (1992). Thylakoid-Bound Ascorbate Peroxidase in Spinach Chloroplasts and Photoreduction of Its Primary Oxidation Product Monodehydroascorbate Radicals in Thylakoids. Plant \& Cell Physiology, Vol. 33, No. 5, (July 1992), pp. 541-553, ISSN 0032-0781

Miyake, C., Schreiber, U., Hormann, H., Sano, S. \& Asada, K. (1998). The FAD-Enzyme Monodehydroascorbate Radical Reductase Mediates Photoproduction of Superoxide Radicals in Spinach Thylakoid Membranes. Plant \& Cell Physiology, Vol. 39, No. 8, (August 1998), pp. 821 - 829, ISSN 0032-0781

Morosinotto, T., Bassi, R., Frigerio, S., Finazzi, G., Morris, E. \& Barber, J. (2006). Biochemical and Structural Analyses of a Higher Plant Photosystem II Supercomplex of a Photosystem I-Less Mutant of Barley. Consequences of a Chronic Over-Reduction of the Plastoquinone Pool. The FEBS Journal, Vol. 273, No. 20, (October 2006), pp. 4616-4630, ISSN 1742-464X 
Mozzo, M., Passarini, F., Bassi, R., van Amerongen, H. \& Croce, R. (2008). Photoprotection in Higher Plants: the Putative Quenching Site is Conserved in All Outer LightHarvesting Complexes of Photosystem II. Biochimica et Biophysica Acta, Vol. 1777, No. 10, (October 2008), pp. 1263-1267, ISSN 0005-2728

Mubarakshina, M., Khorobrykh, S. \& Ivanov, B. (2006). Oxygen Reduction in Chloroplast Thylakoids Results in Production of Hydrogen Peroxide Inside the Membrane. Biochimica et Biophysica Acta, Vol. 1757, No. 11, (November 2006), pp. 1496-1503, ISSN 0005-2728

Mubarakshina, M.M., Ivanov B.N., Naydov I.A., Hillier W., Badger M.R., Krieger-Liszkay A. (2010). Production and diffusion of chloroplastic $\mathrm{H}_{2} \mathrm{O}_{2}$ and its implication to signalling. Journal of Experimental Botany, Vol. 61, No. 13, pp. 3577-3587, ISSN 00220957

Mubarakshina, M.M. \& Ivanov, B.N. (2010). The Production and Scavenging of Reactive Oxygen Species in the Plastoquinone Pool of Chloroplast Thylakoid Membranes. Physiologia Plantarum, Vol. 140, No. 2, (October 2010), pp. 103-110, ISSN 0031-9317

Mullineaux, P. \& Karpinski, S. (2002). Signal Transduction in Response to Excess Light: Getting Out of the Chloroplast. Current Opinion in Plant Biology, Vol. 5, No. 1, (February 2002), pp. 43-48, ISSN 1369-5266

Mullineaux, P.M. (2009). ROS in Retrograde Signalling from the Chloroplast to the Nucleus, In: Reactive Oxygen Species in Plant Signaling. Signaling and Communication in Plants, L.A. Rio \& A. Puppo (Eds), pp. 221-240, Springer, ISBN 978-364-2003-90-5, Berlin Heidelberg, Germany

Munné-Bosch, S., Weiler, E.W., Alegre, L., Müller, M., Düchting, P. \& Falk, J. (2007). aTocopherol May Influence Cellular Signaling by Modulating Jasmonic Acid Levels in Plants. Planta, Vol. 225, No. 3, (February 2007), pp. 681-691, ISSN 0032-0935

Nakano, Y. \& Asada, K. (1980). Spinach Chloroplasts Scavenge Hydrogen Peroxide on Illumination. Plant \& Cell Physiology, Vol. 21, No. 7, (November 1980), pp. 12951307, ISSN 0032-0781

Nakano, Y. \& Asada, K. (1987). Purification of Ascorbate Peroxidase in Spinach Chloroplasts: Its Inactivation in Ascorbate-Depleted Medium and Reactivation by Monodehydroascorbate Radical. Plant \& Cell Physiology, Vol. 28, No., (January 1987), pp. 131-140, ISSN 0032-0781

Neverov, K.V. \& Krasnovsky Jr., A.A. (2004). Phosphorescence Analysis of the Chlorophyll Triplet States in Preparations of Photosystem II. Biofizika, Vol. 49, No. 3, (May-June 2004), pp. 493-498, ISSN 0006-3029

Nishizawa, A., Yukinori, Y. \& Shigeoka, S. (2008). Galactinol and Raffinose as a Novel Function to Protect Plants from Oxidative Damage. Plant Physiology, Vol. 147, No. 3, (July 2008), pp. 1251-1263, ISSN 0032-0889

Nixon, P.J. \& Rich, P.R. (2006). Chlororespiratory Pathways and Their Physiological Significance. In: The Structure and Function of Plastids. Advances in Photosynthesis and Respiration, R.R. Wise \& J.K. Hoober (Eds), pp 237-251,Springer, ISBN 978-140-204061-0, Dordrecht, The Netherlands

Noctor, G., Veljovic-Jovanovic, S. \& Foyer, C.H. (2000). Peroxide Processing in Photosynthesis: Antioxidant Coupling and Redox Signaling. Philosophical Transactions of the Royal Society of London. Series B, Biological Sciences, Vol. 355, No. 1402, (October 2000), pp. 1465-1475, ISSN 0962-8436 
Ogawa, K., Kanematsu, S., Takabe, K. \& Asada, K. (1995). Attachment of CuZn-Superoxide Dismutase to Thylakoid Membranes at the Site of Superoxide Generation (PSI) in Spinach Chloroplasts: Detection by Immuno-Gold Labelling after Rapid Freezing and Substitution Method. Plant \& Cell Physiology, Vol. 36, No. 4, (June 1995), pp. 565-573, ISSN 0032-0781

Op den Camp, R.G.L., Przybyla, D., Ochsenbein, C., Laloi, C., Kim, C., Danon, A., Wagner, D., Hideg, E., Göbel, C., Feussner, I., Nater, M. \& Apel, K. (2003). Rapid Induction of Distinct Stress Responses after the Release of Singlet Oxygen in Arabidopsis. The Plant Cell, Vol. 15, No. 10, (October 2003), pp. 2320-2332, ISSN 1040-4651

Osyczka, A., Moser, C.C., Daldal, F. \& Dutton, P.L. (2004). Reversible Redox Energy Coupling in Electron Transfer Chains. Nature, Vol. 427, No. 6975, (February 2004), pp. 607-612, ISSN 0028-0836

Park, Y.-I., Chow, W.S., Osmond, C.B. \& Anderson, J.M. (1996). Electron Transport to Oxygen Mitigates against the Photoinactivationof Photosystem II in vivo. Photosynthesis Research,, Vol. 50, No. 1, (October 1996), pp. 23-32, ISSN 0166-8595

Peiser, G.D., Lizada, M.C. \& Yang, S.F. (1982). Sulfite-Induced Lipid Peroxidation in Chloroplasts as Determined by Ethane Production. Plant Physiology, Vol. 70, No. 4, (October 1982), pp. 994-998, ISSN 0032-0889

Pfannschmidt, T., Nillson A. \& Allen, J.F. (1999). Photosynthetic Control of Chloroplast Gene Expression. Nature, Vol. 397, No. 6720, (February 1999), pp. 625-628, ISSN 0028-0836

Polle, A.R. \& Rennenberg, H. (1994). Photooxidative Stress in Trees. In: Causes of Photooxidative Stress and Amelioration of Defense Systems in Plants, C.H. Foyer \& P.M. Mullineaux (Eds), pp. 199-209, CRC Press, ISBN 978-084-9354-43-4, Boca Raton, Florida, USA

Pospíšil, P., Arató, A., Krieger-Liszkay, A. \& Rutherford, A.W. (2004). Hydroxyl Radical Generation by Photosystem II. Biochemistry, Vol. 43, No. 21, (June 2004), pp. 67836792, ISSN 0006-2960

Pospíšil, P. (2011) Enzymatic Function of Cytochrome b559 in Photosystem II. Journal of Photochemistry and Photobiology, Vol. 104, No. 1-2, (July-August 2011), pp 341-347, ISSN 1011-1344

Quesada, A.R., Byrnes, R.W., Krezoski, S.O. \& Petering, D.H. (1996). Direct Reaction of $\mathrm{H}_{2} \mathrm{O}_{2}$ with Sulfhydryl Groups in HL-60 Cells: Zinc-Metallothionein and Other Sites. Archives of Biochemistry \& Biophysics, Vol. 334, No. 2, (October 1996), pp. 241-250, ISSN 0003-9861

Rajagopal, S., Egorova, E.A., Bukhov, N.G. \& Carpentier, R. (2003). Quenching of excited states of chlorophyll molecules in submembrane fractions of Photosystem I by exogenous quinones. Biochimica et Biophysica Acta, Vol. 1606, No. 1-3, (September 2003), pp. 147-152, ISSN 0005-2728

Ramon, M., Rolland, F. \& Sheen, J. (2009). Sugar Sensing and Signaling, In: The Arabidopsis Book,06.11.2008, Available http://www.bioone.org/doi/full/10.1199/tab.0117

Reuber, S., Bornman, J.F. \& Weissenbock, G. (1996). Phenylpropanoid Compounds in Primary Leaf Tissues of Rye (Secale cereale). Light Response of Their Metabolism and the Possible Role in UV-B Protection. Physiologia Plantarum, Vol. 97, No. 1, (May 1996), pp. 160-168, ISSN 0031-9317 
Rhee, S.G., Chae, H.Z. \& Kim, K. (2005). Peroxiredoxins: a Historical Overview and Speculative Preview of Novel Mechanisms and Emerging Concepts in Cell Signalling. Free Radical Biology \& Medicine, Vol. 38, No. 12, (June 2005), pp. 15431552, ISSN 0891-5849

Rice-Evans, C.A., Miller, N. \& Paganga, G. (1996). Structure-Antioxidant Relationships of Flavonoids and Phenolic Acids. Free Radical Biology \& Medicine, Vol. 20, No. 7, (n.d.) pp. 933-956, ISSN 0891-5849

Rich, P.R. (1985). Mechanisms of Quinol Oxidation in Photosynthesis. Photosynthesis Research, Vol. 6, No. 4, (December 1985), pp. 335-348, ISSN 0166-8595

Rizhsky, L., Liang, H. \& Mittler, R. (2003). The Water-Water Cycle Is Essential for Chloroplast Protection in the Absence of Stress. The Journal of Biological Chemistry, Vol. 278, No. 40, (October 2003), pp. 38921-38925, ISSN 0021-9258

Robinson, J.M. \& Gibbs, M. (1982). Hydrogen Peroxide Synthesis in Isolated Spinach Chloroplast Lamellae: An Analysis of the Mehler Reaction in the Presence of NADP Reduction and ATP Formation. Plant Physiology, Vol. 70, No. 5, (November 1982), pp. 1249-1254, ISSN 0032-0889

Rutherford, A.W. \& Inoue, Y. (1984). Oscillation of Delayed Luminescence from PSII: Recombination of S2QB and S3QB. FEBS Letters, Vol. 165, No. 2, (January 1984), 163-170, ISSN 0014-5793

Rutherford, A.W. \& Krieger-Liszkay, A. (2001). Herbicide-Induced Oxidative Stress in Photosystem II. Trends in Biochemical Sciences, Vol. 26, No. 11, (November 2001), pp. 648-653, ISSN 0968-0004

Sakamoto, A., Tsukamoto, S., Yamamoto, H., Ueda-Hashimoto, M., Takahashi, M., Suzuki, H. \& Morikawa, H. (2003). Functional Complementation in Yeast Reveals a Protective Role of Chloroplast 2-Cys Peroxiredoxin against Reactive Nitrogen Species. The Plant Journal, Vol. 33, No. 5, (March 2003), pp. 841-851, ISSN 0960-7412

Sarowar, S., Lee, J.-Y., Ahn, E.-R. \& Pai, H.-S. (2008). A Role of Hexokinases in Plant Resistance to Oxidative Stress and Pathogen Infection. Journal of Plant Biology, Vol. 51, No. 5, (September 2008), pp. 341-346, ISSN 1867-0725

Sazanov, L.A., Burrows, P.A. \& Nixon, P.J. (1998). The Chloroplast Ndh Complex Mediates the Dark Reduction of the Plastoquinone Pool in Response to Heat Stress in Tobacco Leaves. FEBS Letters, Vol. 429, No. 1, (June 1998), pp. 115-118, ISSN 00145793

Scarpeci, T.E., Zanor, M.I., Carrillo, N., Mueller-Roeber, B. \& Valle, E.M. (2008). Generation of Superoxide Anion in Chloroplasts of Arabidopsis thaliana during Active Photosynthesis: A Focus on Rapidly Induced Genes. Plant Molecular Biology, Vol. 66, No. 4, (March 2008), pp. 361-378, ISSN 0167-4412

Scheibe, R. \& Dietz, K.J. (2011). Reduction-Oxidation Network for Flexible Adjustment of Cellular Metabolism in Photoautotrophic Cells. Plant, Cell $\mathcal{E}$ Environment, doi: 10.1111/j.1365-3040.2011.02319.x

Sharkey, T.D. (1988). Estimating the Rate of Photorespiration in Leaves. Physiologia Plantarum, Vol. 73, No. 1, (May 1988), pp. 147-152, ISSN 0031-9317

Shen, B., Jensen, R.G. \& Bohnert, H.J. (1997). Increased Resistance to Oxidative Stress in Transgenic Plants by Targeting Mannitol Biosynthesis to Chloroplasts. Plant Physiology, Vol. 113, No. 4, (April 1997), pp. 1177-1183, ISSN 0032-0889 
Sichel, G., Corsaro, C., Scalia, M., di Bilio, A. \& Bonomo, R.P. (1991). In vitro Scavenger Activity of Some Flavonoids and Melanins against $\mathrm{O}_{2}{ }^{-}$. Free Radical Biology $\mathcal{E}$ Medicine, Vol. 11, No. 1, (n.d.), pp. 1-8, ISSN 0891-5849

Smirnoff, N. \& Cumbes, Q.J. (1989). Hydroxyl Radical Scavenging Activity of Compatible Solutes. Phytochemistry, Vol. 28, No. 4, (n.d.), pp. 1057-1060, ISSN 0031-9422

Smirnoff, N. (2000). Ascorbate Biosynthesis and Function in Photoprotection. Philosophical Transactions of the Royal Society of London. Series B, Biological Sciences, Vol. 355, No. 1402, (October 2000), pp. 1455-1464, ISSN 0962-8436

Snyrychova, I., Pospisil, P. \& Naus, J. (2006). Reaction Pathways Involved in the Production of Hydroxyl Radicals in Thylakoid Membrane: EPR Spin-Trapping Study. Photochemical \& Photobiological Sciences, Vol. 5, No. 5, (May 2006), pp 472-476, ISSN 1474-905X

Srivastava, S., Phadke, R.S., Govil, G. \& Rao, C.N.R. (1983). Fluidity, Permeability and Antioxidant Behaviour of Model Membranes Incorporated with a-Tocopherol and Vitamin E Acetate. Biochimica et Biophysica Acta, Vol. 734, No. 2, (October 1983), pp. 353-362, ISSN 0005-2728

Stewart, D. \& Brudvig, G. (1998). Cytochrome b559 of Photosystem II. Biochimica et Biophysica Acta, Vol. 1367, No. 1-3, (October 1998), pp. 63-87, ISSN 0005-2728

Streb, P., Feierabend, J. \& Bligny, R. (1997). Resistance to Photoinhibition of Photosystem II and Catalase and Antioxidative Protection in High Mountain Plants. Plant, Cell $\mathcal{E}$ Environment, Vol. 20, No. 8, (August 1997), pp. 1030 - 1040, ISSN 0140-7791

Sun, L., Shukair, S., Naik, T.J., Moazed, F. \& Ardehali, H. (2008). Glucose Phosphorylation and Mitochondrial Binding Are Required for the Protective Effects of Hexokinases I and II. Molecular \& Cellular Biology, Vol. 28, No. 3, (February 2008), pp. 1007-1017, ISSN0270-7306

Suzuki, N., Koussevitzky, S., Mittler, R. \& Miller, G. (2011). ROS and redox signalling in the response of plants to abiotic stress. Plant, Cell $\mathcal{E}$ Environment, doi: 10.1111/j.13653040.2011.02336.x

Székely, G., Abrahám, E., Cséplo, A., Rigó, G., Zsigmond, L., Csiszár, J., Ayaydin, F., Strizhov, N., Jásik, J., Schmelzer, E., Koncz, C. \& Szabados, L. (2008). Duplicated P5CS Genes of Arabidopsis Play Distinct Roles in Stress Regulation and Developmental Control of Proline Biosynthesis. The Plant Journal, Vol. 53, No. 1, (January 2008), pp. 11-28, ISSN 0960-7412

Szymańska, R. \& Kruk, J. (2010). Plastoquinol is the Main Prenyllipid Synthesized During Acclimation to High Light Conditions in Arabidopsis and is Converted to Plastochromanol by Tocopherol Cyclase. Plant \& Cell Physiology, Vol. 51, No. 4, (April 2010), pp. 537-545, ISSN 0032-0781

Takahashi, M.A. \& Asada, K. (1983). Superoxide Anion Permeability of Phospholipids Membranes and Chloroplast Thylakoids. Archives of Biochemistry and Biophysics, Vol. 266, No. 2, (October 1983), pp. 558-566, ISSN 0003-9861

Takahashi, M. \& Asada, K. (1988). Superoxide Production in Aprotic Interior of Chloroplast Thylakoids. Archives of biochemistry \& biophysics, Vol. 267, No. 2, (December 1988), pp. 714-722, ISSN 0003-9861

Theil, E.C. (2004) Iron, Ferritin, and Nutrition. Annual Review of Nutrition, Vol. 24, (July 2004), pp. 327-343, ISSN 0199-9885 
Thomas, C.E., Morehouse, L.A. \& Aust, S.D. (1985). Ferritin and Superoxide-Dependent Lipid Peroxidation. The Journal of Biological Chemistry, Vol. 260, No. 6, (March 1985), pp. 3275-3280, ISSN 0021-9258

Tjus, S.E., Scheller, H.V., Andersson, B. \& Møller, B.L. (2001). Active Oxygen Produced during Selective Excitation of Photosystem I Is Damaging not Only to Photosystem I, but Also to Photosystem II. Plant Physiology, Vol. 125, No. 4, (April 2001), pp. 2007-2015, ISSN 0032-0889

Trebst A., Depka, B. \& Holländer-Czytko, H. (2002). A Specific Role for Tocopherol and of Chemical Singlet Oxygen Quenchers in the Maintenance of Photosystem II Structure and Function in Chlamydomonas reinhardii. FEBS Letters, Vol. 516, No. 1-3, (April 2002), pp. 156-160, ISSN 0014-5793

Vernooij, B., Friedrich, L., Morse, A., Reist, R., Kolditz-Jawhar, R., Ward, E., Uknes, S., Kessmann, H. \& Ryals, J. (1994). Salicylic Acid Is Not the Translocated Signal Responsible for Inducing Systemic Acquired Resistance but Is Required in Signal Transduction. The Plant Cell, Vol. 6, No. 7, (July 1994), pp. 959-965, ISSN 1040-4651

von Gromoff, E.D., Schroda, M., Oster, U. \& Beck, C.F. (2006). Identification of a Plastid Response Element that Acts as an Enhancer within the Chlamydomonas HSP70A Promoter. Nucleic Acids Research, Vol. 34, No. 17, (October 2006), pp. 4767-4779, ISSN 0305-1048

Wang, P.T. \& Song, C.P. (2008). Guard-Cell Signalling for Hydrogen Peroxide and Abscisic Acid. The New Phytologist, Vol. 178, No. 4, (June 2008), pp. 703-718, ISSN 0028-646X

Wang, S.Y. \& Jiao, H. (2000). Scavenging Capacity of Berry Crops on Superoxide Radicals, Hydrogen Peroxide, Hydroxyl Radicals, and Singlet Oxygen. Journal of Agricultural and Food Chemistry, Vol. 48, No. 11, (November 2000), 5677-5684, ISSN 0021-8561

Wasilewska, A., Vlad, F., Sirichandra, C., Redko, Y., Jammes, F., Valon, C., Frei dit Frey, N. \& Leung, J. (2008). An Update on Abscisic Acid Signaling in Plants and More... Molecular Pant, Vol. 1, No. 2, (March 2008), pp. 198-217, ISSN 1674-2052

Wasternack, C. (2007). Jasmonates: an Update on Biosynthesis, Signal Transduction and Action in Plant Stress Response, Growth and Development. Annals of Botany, Vol. 100, No. 4, (October 2007), pp. 681-697, ISSN 0305-7364

Wei, Y., Dang, X. \& Hu, S. (2004). Electrochemical Properties of Superoxide Ion in Aprotic Media. Russian Journal of Electrochemistry, Vol. 40, No. 4, (April 2004), pp. 400-403, ISSN 1023-1935

Wingler, A., Lea, P.J., Quick, W.P. \& Leegood, R,C. (2000). Photorespiration: Metabolic Pathways and Their Role in Stress Protection. Philosophical Transactions of the Royal Society of London. Series B, Biological Sciences, Vol. 355, No. 1402, (October 2000), pp. 1517-1529, ISSN 0962-8436

Winterbourn, C.C. \& Metodiewa, D. (1994). The Reaction of Superoxide with Reduced Glutathione. Archives of Biochemistry and Biophysics, Vol. 314, No. 2, (November 1994), pp. 284-290, ISSN 0003-9861

Woo, K.C. (1983). Evidence for Cyclic Photophosphorylation during CO(2) Fixation in Intact Chloroplasts: Studies with Antimycin A, Nitrite, and Oxaloacetate. Plant Physiology, Vol. 72, No. 2, (June 1983), pp. 313-320, ISSN 0032-0889

Yadav, D.K., Kruk, J., Sinha, R.K. \& Pospíšil, P. (2010). Singlet Oxygen Scavenging Activity of Plastoquinol in Photosystem II of Higher Plants: Electron Paramagnetic 
Resonance Spin-Trapping Study. Biochimica et Biophysica Acta, Vol. 1797, No. 11, (November 2010), pp. 1807-1811, ISSN 0005-2728

Yang, D.H., Andersson, B., Aro, E.M. \& Ohad, I. (2001). The Redox State of the Plastoquinone Pool Controls the Level of the Light-Harvesting Chlorophyll $\mathrm{a} / \mathrm{b}$ Binding Protein Complex II (LHC II) during Photoacclimation. Photosynthesis Research, Vol. 68, No. 2, (May 2001), pp. 163-174, ISSN 0166-8595

Yun, K.Y., Park, M.R., Mohanty, B., Herath, V., Xu, F.Y., Mauleon, R., Wijaya, E., Bajic, V.B., Bruskiewich, R. \& de Los Reyes, B.G. (2010). Transcriptional Regulatory Network Triggered by Oxidative Signals Configures the Early Response Mechanisms of Japonica Rice to Chilling Stress. BMC Plant Biology, Vol. 10:16, (January 2010), pp., ISSN 1471-2229

Yurina, N.P. \& Odintsova, M.S. (2007). Plant Signaling Systems. Plastid-Generated Signals and Their Role in Nuclear Gene Expression. Russian Journal of Plant Physiology, Vol. 54, No. 4, (July 2007), pp. 427-438, ISSN 1021-4437

Zelitch, I., Schultes, N.P., Peterson, R.B., Brown, P. \& Brutnell, T.P. (2008). High Glycolate Oxidase Activity Is Required for Survival of Maize in Normal Air. Plant Physiology, Vol. 149, No. 1, (January 2008), pp. 195-204, ISSN 0032-0889

Ziem-Hanck, U. \& Heber, U. (1980). Oxygen Requirement of Photosynthetic $\mathrm{CO}_{2}$ Assimilation. Biochimica et Biophysica Acta, Vol. 591, No. 2, (July 1980), pp. 266-274, ISSN 0005-2728 


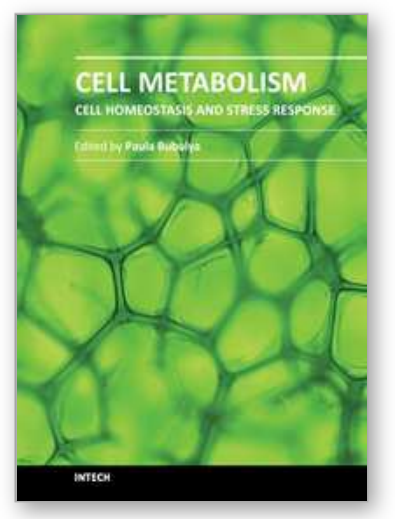

\author{
Cell Metabolism - Cell Homeostasis and Stress Response \\ Edited by Dr. Paula Bubulya
}

ISBN 978-953-307-978-3

Hard cover, 208 pages

Publisher InTech

Published online 25, January, 2012

Published in print edition January, 2012

A global research community of scientists is teasing out the biochemical mechanisms that regulate normal cellular physiology in a variety of organisms. Much of current research aims to understand the network of molecular reactions that regulate cellular homeostasis, and to learn what allows cells to sense stress and activate appropriate biochemical responses. Advanced molecular tools and state-of-the-art imaging techniques discussed in this book continue to provide novel insights into how environmental changes impact organisms, as well as to develop therapeutic interventions for correcting aberrant pathways in human disease.

\title{
How to reference
}

In order to correctly reference this scholarly work, feel free to copy and paste the following:

Boris Ivanov, Marina Kozuleva and Maria Mubarakshina (2012). Oxygen Metabolism in Chloroplast, Cell Metabolism - Cell Homeostasis and Stress Response, Dr. Paula Bubulya (Ed.), ISBN: 978-953-307-978-3, InTech, Available from: http://www.intechopen.com/books/cell-metabolism-cell-homeostasis-and-stressresponse/oxygen-metabolism-in-chloroplasts

\section{INTECH}

open science | open minds

\section{InTech Europe}

University Campus STeP Ri

Slavka Krautzeka 83/A

51000 Rijeka, Croatia

Phone: +385 (51) 770447

Fax: +385 (51) 686166

www.intechopen.com

\section{InTech China}

Unit 405, Office Block, Hotel Equatorial Shanghai

No.65, Yan An Road (West), Shanghai, 200040, China

中国上海市延安西路65号上海国际贵都大饭店办公楼 405 单元

Phone: +86-21-62489820

Fax: +86-21-62489821 
(C) 2012 The Author(s). Licensee IntechOpen. This is an open access article distributed under the terms of the Creative Commons Attribution 3.0 License, which permits unrestricted use, distribution, and reproduction in any medium, provided the original work is properly cited. 